\title{
Main drivers of broomrape regulation. A review
}

\author{
Dïnia Cartry ${ }^{1}$ (D) $\cdot$ Christian Steinberg $^{1}$ (D) $\cdot$ Stéphanie Gibot-Leclerc ${ }^{1,2}$ (D)
}

Accepted: 12 January 2021 / Published online: 24 February 2021

(C) INRAE and Springer-Verlag France SAS, part of Springer Nature 2021

\begin{abstract}
Orobanchaceae - broomrapes - are a family of parasitic plants that represent an ecological and agronomic challenge because some of them cause significant damage to many monocots or dicots. Weedy broomrapes infest different crops in the Mediterranean basin, leading to substantial yield losses. Besides, they quickly adapt to new host plants, so that new crops are more and more under threat. Control methods are lacking because as plant parasites they cannot be considered as a common weed in agriculture. It is therefore important to characterize the main drivers of their regulation to identify sustainable management strategies.

We reviewed all the possible interactions of Orobanchaceae species with surrounding organisms in an agricultural landscape, with a focus on the Orobanche and Phelipanche genera. Our main findings are that (1) broomrapes successfully co-evolve with their host through tight interactions ranging from the molecular to the tissue level, resulting in a unique strategy in their interactions with their host; (2) broomrapes have to face natural regulatory mechanisms such as host plant defenses, allelopathic interferences, and pest attacks from both the rhizosphere and phyllosphere; (3) alternative methods combining these natural mechanisms with existing conventional methods should be used to control broomrape. Conventional methods have shown limited results with parasitic weeds. By considering their life cycle and biotic and abiotic environment, management methods will target their weak point(s). Combining different control methods needs to be considered in an integrated weed management system. Furthermore, future studies on biocontrol will bring out new products to be used in addition to cultural techniques. Modeling approaches would help predict the evolution of broomrape-infested plots and the available potential management strategies.
\end{abstract}

Keywords Orobanchaceae Parasitic plant · Biotic interactions · Weed management - Regulation · Rhizosphere . Microorganisms $\cdot$ Biocontrol

\section{Contents}

1. Introduction

2. Parasitic weeds in agriculture

3. Broomrape-host plant interactions

3.1 Broomrape diversity

3.2 Strigolactones: the first contact

Stéphanie Gibot-Leclerc

stephanie.gibot-leclerc@inrae.fr

1 INRAE, UMR 1347 Agroécologie Pôle GestAD, Bâtiment Coste, Agroécologie, AgroSup Dijon, INRAE, Univ. Bourgogne, Univ. Bourgogne Franche-Comté, F-21000 Dijon, France

2 INRAE, UMR 1347 Agroécologie Pôle GestAD, Bâtiment Coste, Agroécologie, AgroSup Dijon, INRAE, Univ. Bourgogne, Univ. Bourgogne Franche-Comté, 17 rue Sully, BP 86510, 21065 Dijon Cedex, France
3.3 Specificity of the interactions with the host plant

3.4 Plant defense reactions

4. Broomrape regulation mechanisms

4.1 Background

4.2 Regulation of broomrape by allelopathy

4.3 Regulation of broomrape by pests

4.4 Regulation of broomrape by soil-borne microorganisms

4.5 Regulation, unless it be control attempts, of broomrape by human activities

4.6 Biocontrol? Yes, but in what way?

5. Conclusion

Acknowledgements

References 


\section{Introduction}

Agriculture is facing new challenges because of different variables such as climate, pest management, health issues, and societal and economic interests. Conventional practices are running out of stream. For example, the use of pesticides for management purposes is more and more debated. In Europe, more than $30 \mathrm{~kg} / \mathrm{ha} /$ year of pesticides are spread on croplands (Zhang et al. 2015). This poses diverse ecological and human health issues (Lushchak et al. 2018). The extensive use of pesticides has led to resistance of targeted weeds over time (Baucom 2019). The negative impacts and declining effectiveness of pesticides call for new ecological practices to meet societal demands. Agroecology emerged in the 1930s. It can be considered as a new science, new practices, or a new movement (Wezel et al. 2009; Gallardo-López et al. 2018). It tries to bring together high crop yields and the health and wellbeing of people and ecosystems in the absence of chemical inputs. In 2009, the European Commission established a directive aimed at achieving "sustainable use" of pesticides (Salliou and Barnaud 2017). More than 1300 articles with "agroecology" in their title or keywords have been written in the past 5 years, compared to 81 published in the 1990s on the Web of Science Research. Besides, a positive correlation between agroecology and ecosystem services is now clearly established (Palomo-Campesino et al. 2018). This encourages the development of new agricultural, agroecological practices.

One of the main issues faced by modern agriculture is weed management (Hatcher and Froud-Williams 2017). Weeds can be any species whose growth is not expected in a field and that multiply there momentarily. Potential losses caused by weeds average $34 \%$ for six major crop plants: wheat, maize, rice, potato, soybean, and cotton, i.e., as much as the cumulative losses caused by pests, pathogens, and viruses in these same crops (19\%, 13.2\%, and 2.9\%, respectively) (Oerke 2006). Weeds rapidly adapt in anthropized lands, where they are more tolerant and resistant to biotic and abiotic factors (Cirillo et al. 2018). They are extensively studied because of their economic weight and distinctive biology (Neve et al. 2018). Many management techniques have been developed to control weeds in an agroecology context (Cordeau et al. 2016; Jensen 2018), or even use them in a beneficial way for crops (Blaix et al. 2018).

Some weedy species directly reduce crop biomass through a parasitic strategy (Fig. 1). Parasitism is a very successful life strategy: the parasite bypasses all of its host's structural and immune defenses and extracts all the resources it needs while keeping its host alive to complete its cycle (Westwood et al. 2010; Poulin 2014). This close interaction between the parasite (a parasitic weed in the present case), and its host (a cultivated plant), makes pest control particularly complex.

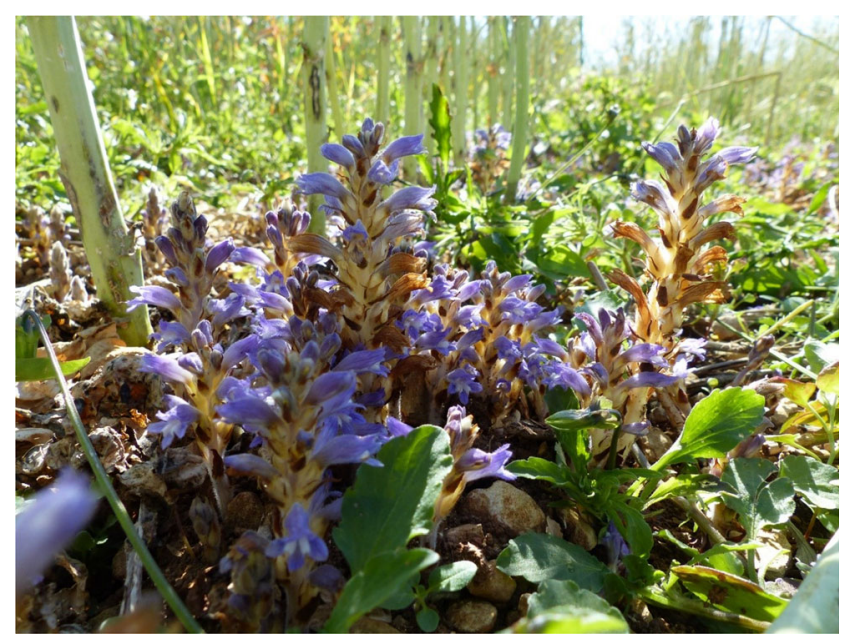

Fig. 1 Example of a Phelipanche ramosa (branched broomrape) parasitic plant in a winter rapeseed field in the Deux-Sèvres "department" (France)

However, this same parasite is also subject to natural regulatory mechanisms whose intensity is modulated by environmental abiotic factors.

The present review briefly examines the characteristics of parasitic plants, and more particularly those of Orobanchaceae. Then, the main drivers of broomrape regulation and their role in broomrape development are addressed. Finally, the use of these drivers as levers of sustainable management is reviewed.

\section{Parasitic weeds in agriculture}

Parasitic weeds are a subset of weeds whose functional and phenotypic traits are very distinct from those of common nonparasitic weeds. All parasitic plants but one are angiosperms. These plants use a specific organ called a haustorium to bind to their host plant, to create a morphological and physiological connection with the host plant (Kuijt 1969; Heide-Jørgensen 2008). There are 4400 species of flowering parasitic plants worldwide, distributed in 270 genera. Only 25 genera or so have a negative impact on cultivated plants, and are considered to be noxious weeds. Parasitic plants remain a concern in agriculture worldwide because they cause severe damage and losses to crops (Parker 2009; Das et al. 2020).

However, "parasitic plants" as such have not been the subject of many scientific articles until late. According to the WoS database $(05 / 11 / 2020)$, only one or two studies were published annually between the 1950s and 1990. In the 1990s, four to five articles were published each year, and it was not until the 2000s that numbers soared, with more than 80 studies published in 2019. Part of these publications addressed Orobanchaceae. Since Linnaeus erected the genus Orobanche in his Species Plantarum in 1753 (http://wssa. net/wp-content/themes/WSSA/WorldOfWeeds/orobanche. $\mathrm{html}$ ), this family has consistently aroused interest from a few 
scientists. However, interest has really grown since the "Third International Workshop on Orobanche and Related Striga Research" that took place in Amsterdam in November 1993, with nearly 80 papers published in 1994. Since then, the number of scientific publications has grown considerably, reaching more than 100 papers per year in the past 10 years. Surprisingly, and although Orobanche are widespread damaging parasitic plants, the name "parasitic plants" is not the most commonly used one in studies on Orobanchaceae: only 380 references published between 1955 and 2020 were retrieved from the WoS database using the combined keywords orobanch* AND "parasitic plants," whereas 2132 and 1073 references were retrieved for the same period using the keywords orobanch* and "parasitic plants," respectively.

Orobanchaceae are mainly studied as plants with their own characteristics (Table 1). They are also studied for their damaging impact in agriculture and their evolutionary traits or the co-evolutionary traits shared with their host plants. Surprisingly, Orobanchaceae attract many scientists, especially chemists and biochemists, for the pharmaceutical and allelopathic interest of molecules they synthesize (almost 30\% of the publications fall into these categories), and for the phytohormones they perceive as stimulants necessary for their development (Table 1). Among these, a family of molecules - strigolactones, see below-have been under special and growing focus, especially since the end of the 2000s (around 15 articles have been published annually on broomrape strigolactones since 2010). Conversely, studies on the biocontrol of Orobanchaceae remain very limited, with an average 3.2 papers / year (WoS, 06 November 2020).

Orobanchaceae are the largest family of parasitic plants (Table 2, Joel 2013). It includes 12 major weeds that belong to the Alectra, Orobanche, Phelipanche, and Striga genera and devastate millions of hectares of major crops worldwide (Asteraceae, Fabaceae, Poaceae, Solanaceae) (Parker 2013). In an infested plot, 5 to $100 \%$ of the yield can be lost because of Orobanche spp. (Parker 2009). In Africa, rice crops suffer from widespread parasitic weeds, and more specifically from Striga spp. and Rhamphicarpa fistulosa (Rodenburg et al. 2016). Their damage to crops has been estimated to be 1 billion US dollars per annum (Spallek et al. 2013). Many European countries, including France, Italy, Spain, and Turkey, are facing significant yield and economic losses estimated to be between 50 and 200 million euros, depending on the crop (Parker 2009; Twyford 2018). For example, Turkey's lentil fields are heavily infested by different species (O. crenata, P. aegyptiaca, and $P$. ramosa), and this leads to 60 million euros of annual economic loss (Aksoy et al. 2016). No effective curative method can currently knock out the parasite without affecting the host plant. Crops have been abandoned and put in quarantine or replaced to avoid infestation by the parasite (Parker 2009). However, infestation remains possible because of the established soil seed bank (Haring and Flessner 2018).
Table 1 WoS categories in which the various publications relating to orobanch*, "parasitic plants," and the "orobanch"" AND "parasitic plants" combination are indexed (WoS, 06 November 2020)

\begin{tabular}{llll}
\hline WoS categories & orobanch* & parasitic plants & orobanch* AND "parasitic plants" \\
\hline Plant sciences & 1311 & 601 & 245 \\
Agronomy & 567 & 93 & 55 \\
Biochemistry molecular biology & 160 & 117 & 48 \\
Evolutionary biology & 112 & 73 & 13 \\
Entomology & 109 & 37 & 23 \\
Ecology & 94 & 153 & 22 \\
Biotechnology applied microbiology & 91 & 29 & 15 \\
Agriculture multidisciplinary & 90 & 25 & 20 \\
Genetics heredity & 79 & 66 & 14 \\
Chemistry medicinal & 69 & 16 & 5 \\
Horticulture & 66 & 19 & 9 \\
Chemistry applied & 58 & 13 & 10 \\
Multidisciplinary sciences & 55 & 65 & 14 \\
Pharmacology pharmacy & 55 & 9 & 2 \\
Chemistry organic & 52 & 11 & 4 \\
Food science technology & 51 & 13 & 12 \\
Environmental sciences & 40 & 16 & 6 \\
Chemistry multidisciplinary & 38 & 18 & 6 \\
Biology & 34 & 29 & 10 \\
Cell biology & 30 & 35 & \\
\hline & & & \\
\hline
\end{tabular}




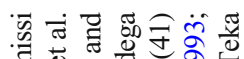

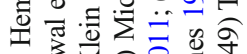

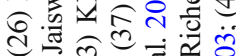

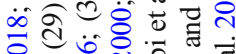

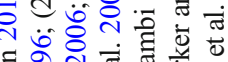

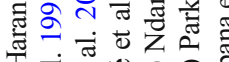

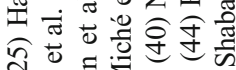

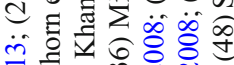

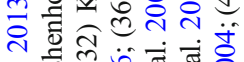

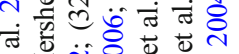

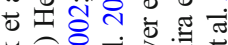

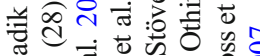

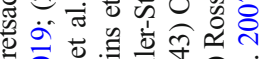

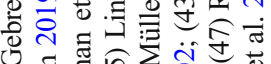

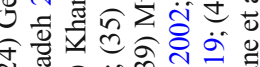

व.

的司

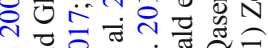

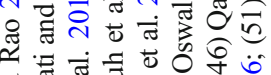

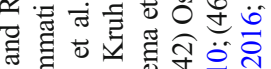

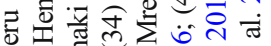

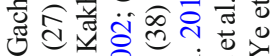

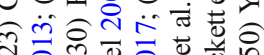

वृत्त

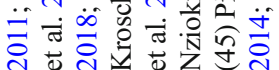

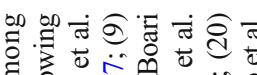

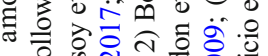

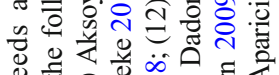

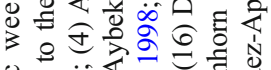

on

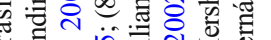

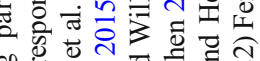

op

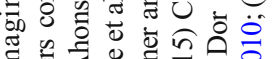

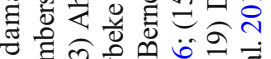

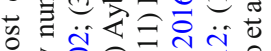
a $\overrightarrow{0} 00$

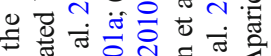

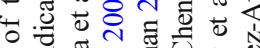

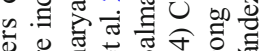

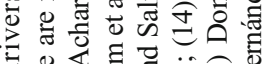

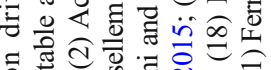

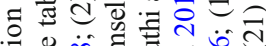

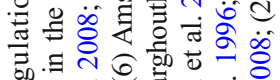
5.

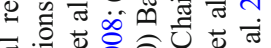
可

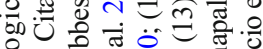

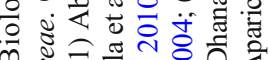
过 $\sim \cong \tilde{0}$

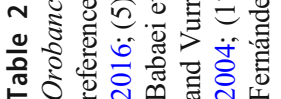
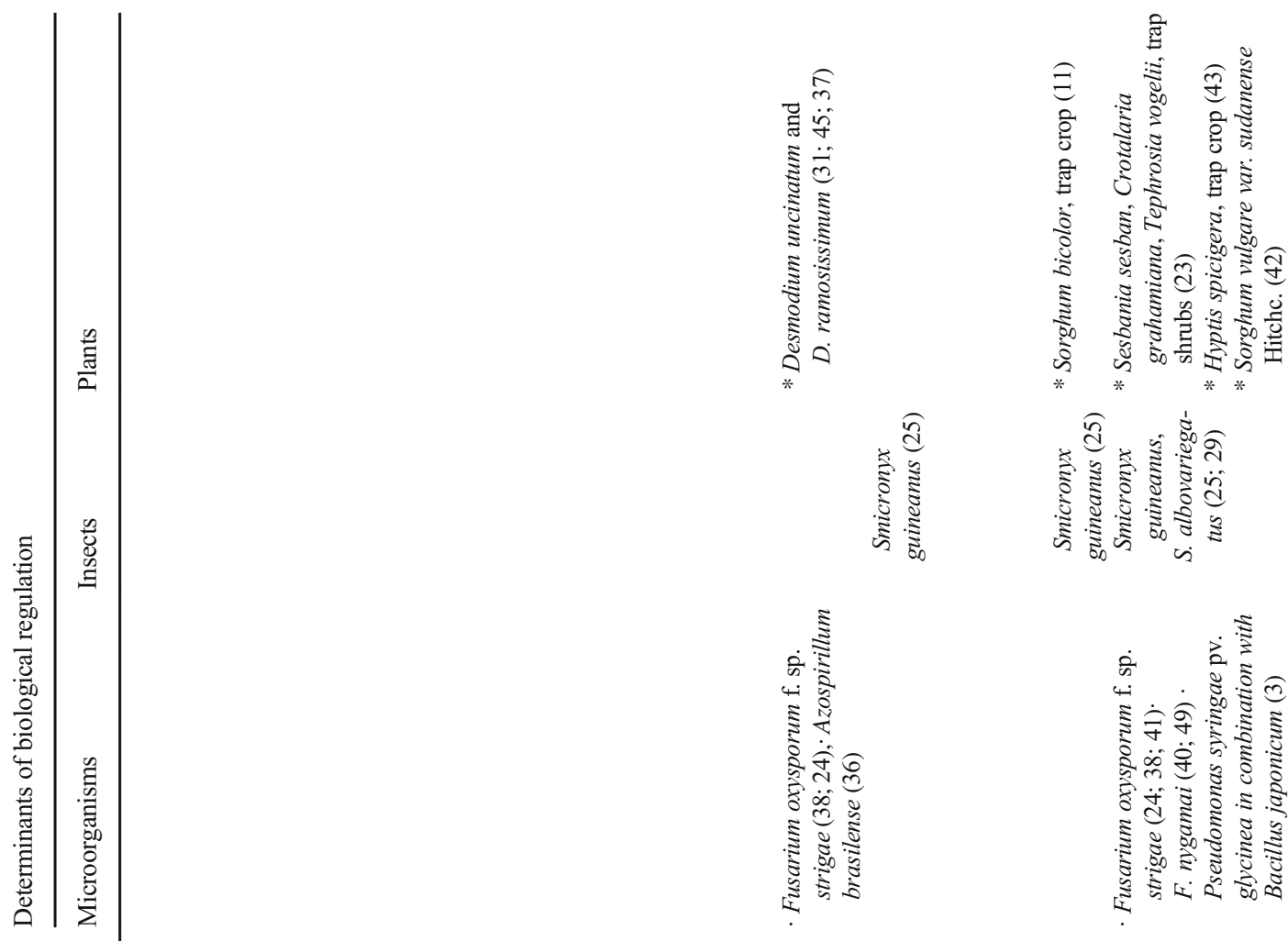

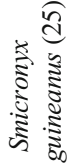

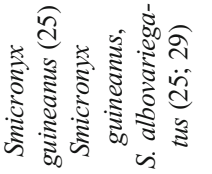

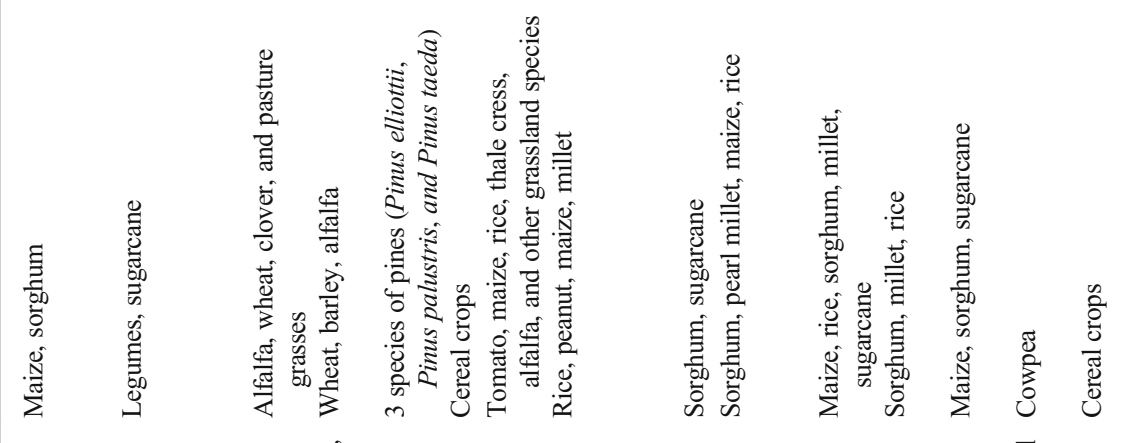

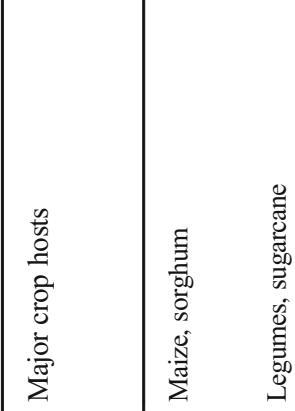

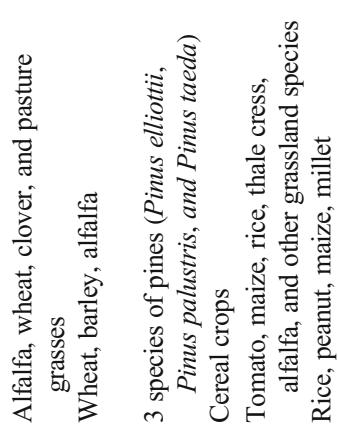

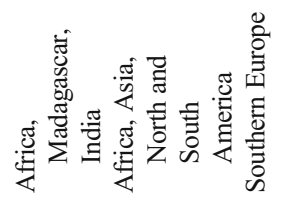

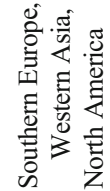

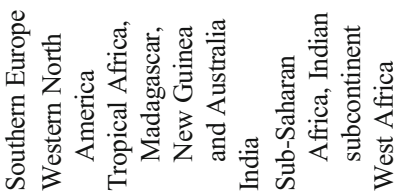

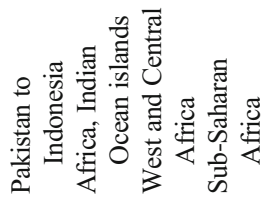

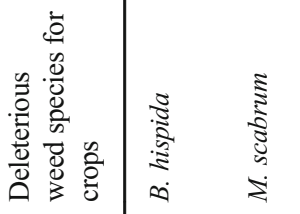

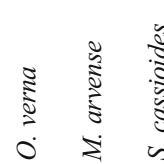

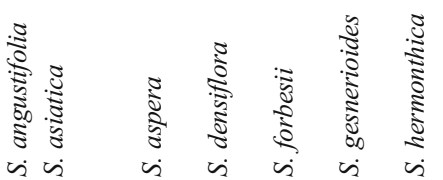

蓆

일윰 8

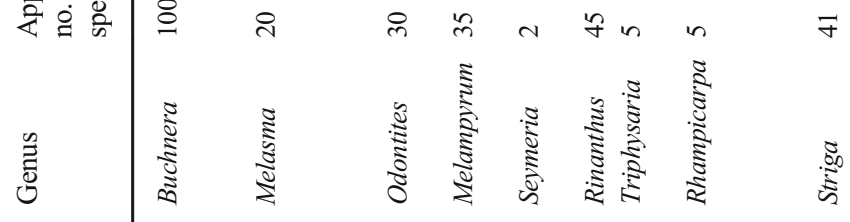

F

ভ 


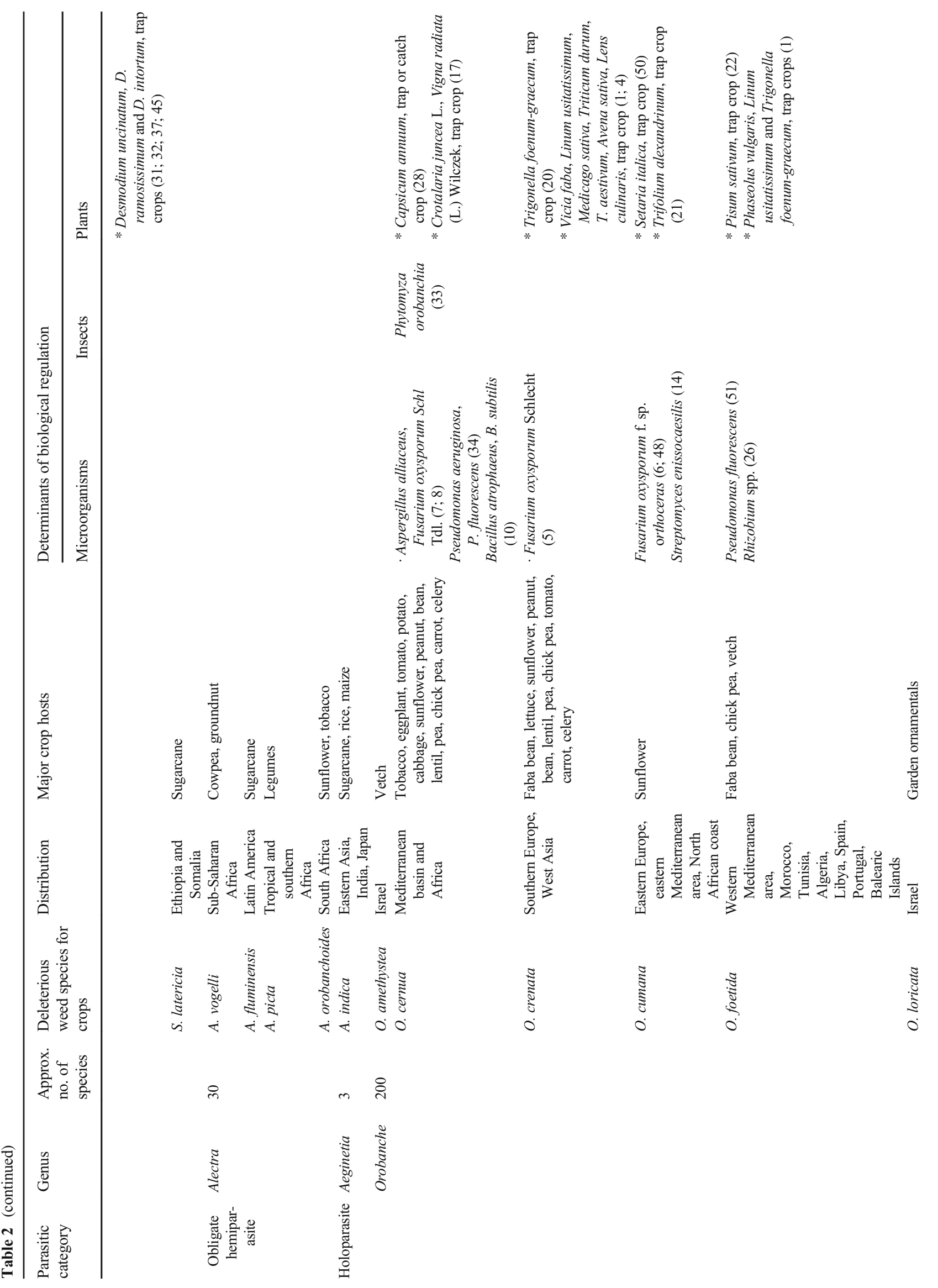

INRAe פ̂s sringr 


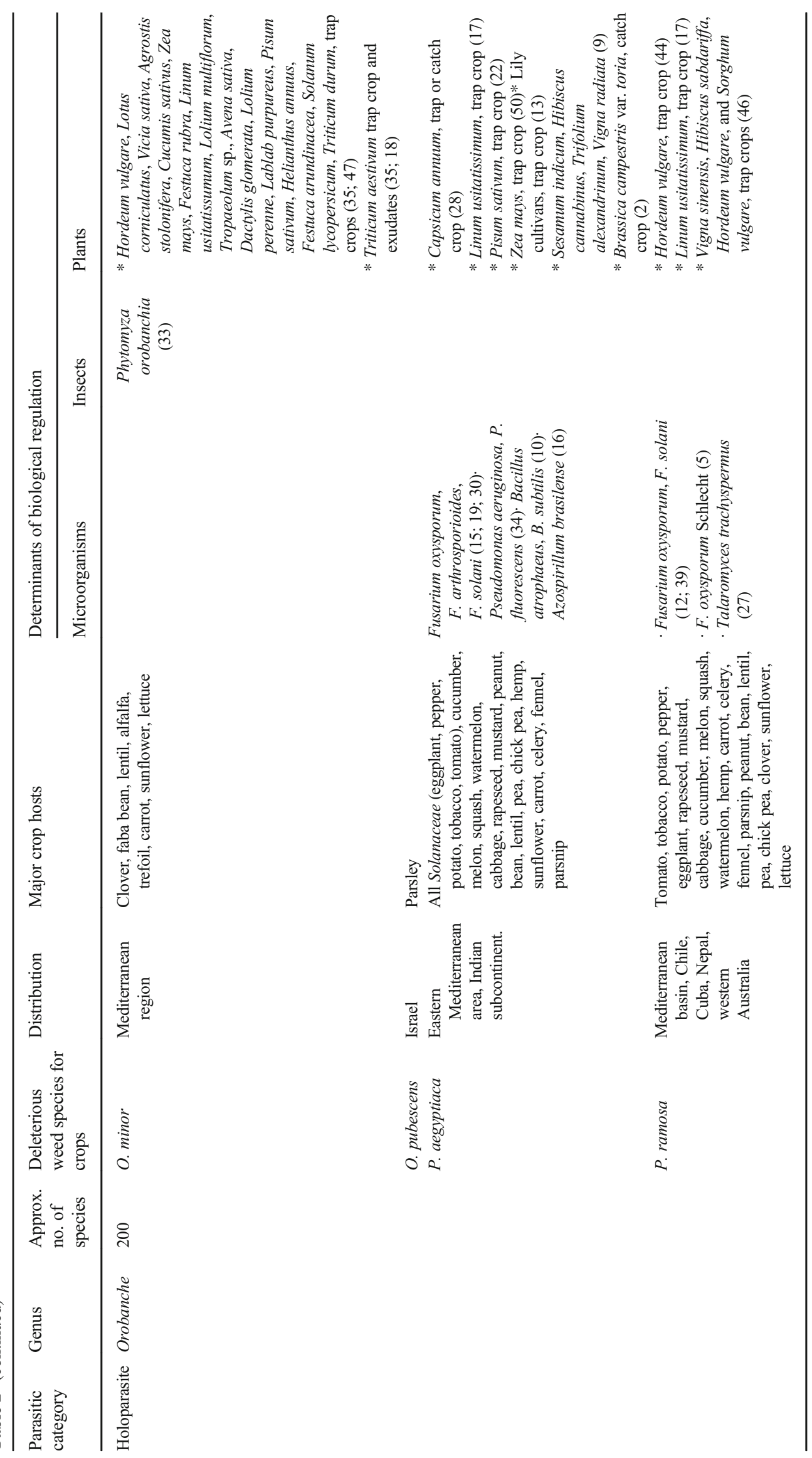


Orobanchaceae include 2000 species of root-specific (epirhizal) parasites, but no stem (epiphyte) parasite (Sanchez Pedraja et al. 2005). Those root-parasitic plants can also be distinguished according to their trophic possibilities. Holoparasites lack chlorophyll and exclusively depend on their host for nutrition; they are called obligate parasites and represent less than $20 \%$ of Orobanchaceae (McNeal et al. 2013). Most Orobanchaceae are hemiparasites, i.e., they contain chlorophyll and can photosynthesize (Heide-Jørgensen 2008; Joel 2013). Some hemiparasites like R. fistulosa can complete their life cycle in the absence of a host plant, even if they grow and reproduce better when fixed on a host. Their parasitic trait is facultative because they can photosynthesize and subsist alone (Rodenburg et al. 2015; Houngbédji et al. 2016, 2020). Other hemiparasites like Striga spp. (also called witchweeds) are obligate root hemiparasites, and their photosynthetic capacity is reduced compared to other green plants (Heide-Jørgensen 2008). They need a host plant to germinate and grow in the soil; they photosynthesize once they emerge from the soil, but are still dependent on their host for the rest of their life cycle (Spallek et al. 2013). However, the facultative/ obligate hemiparasitism paradigm is currently being called into question: a continuum between these so-called facultative and obligate parasites seems to exist. Therefore, these categories should soon be dropped (Těšitel 2016).

Parasitic plants are common worldwide, and have been described by botanists. Owing to their problematic nature, scientists study them closely from different angles. They still remain challenging because they infest and adapt to new terrestrial ecosystems in modern agriculture, and management levers are lacking. A holistic view of parasitic plants in a cultivated plot is presented in Fig. 2. The present review is mainly focused on Orobanche and Phelipanche root holoparasitic species commonly called broomrapes (HeideJørgensen 2008; Joel 2009). Broomrapes infest host plants with variable morphological, physiological, and life history traits (Table 2). Host plant-parasitic plant interactions notably involve chemical signals determining host specificity and in turn host range (Gilbert et al. 2012; Yoshida and Shirasu 2012), with specific traits of parasitic plants involved in their compatibility with the host plant.

\section{Broomrape-host plant interactions}

\subsection{Broomrape diversity}

Orobanche and Phelipanche are the largest genera among Orobanchaceae. They include approximately 200 broomrape species (Parker 2009). They infest a wide range of plants in the Mediterranean basin, including some of the most important crop plants such as oilseed rape, sunflower, tobacco, tomato, and weeds too (Gibot-Leclerc et al. 2003; Parker 2009).

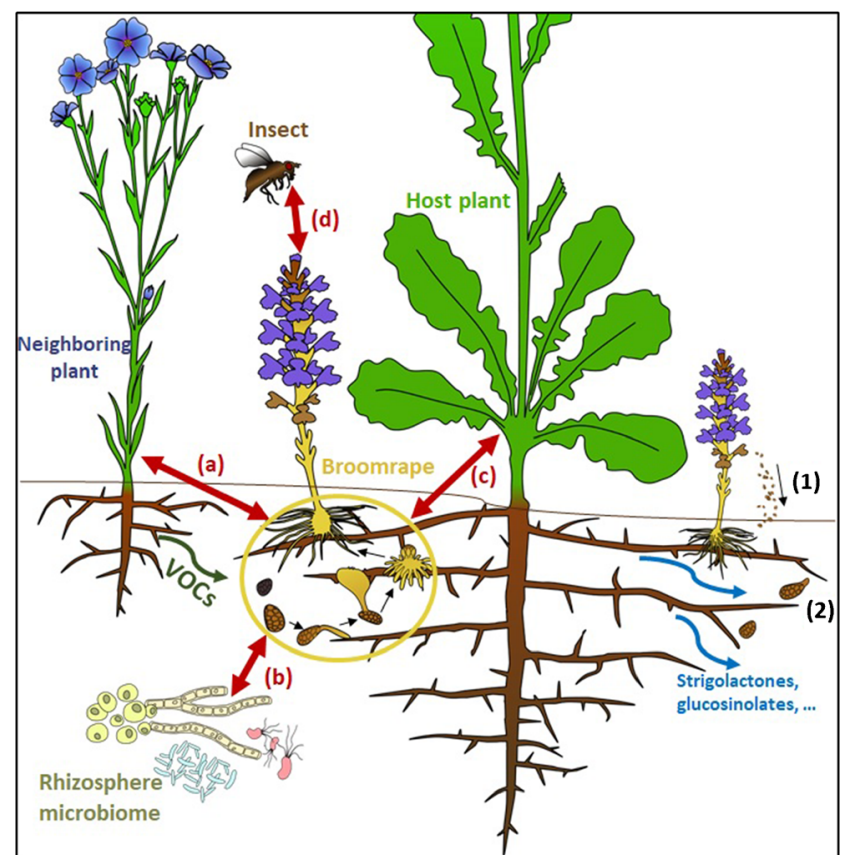

Fig. 2 Biological regulation of broomrapes. Positive regulation: (1) production by each flower scape of hundreds of thousands of seeds able to survive in the soil for more than 10 years; (2) production by the host plant of strigolactones or glucosinolates that stimulate seed germination (blue arrows). Negative regulation in the rhizosphere $(a, b, c)$ and aboveground (d) (bidirectional red arrow): (a) production of allelopathic molecules released by neighboring plants, including VOCs and misleading strigolactones (green arrow); (b) infection by pathogens; (c) host plant defense reactions; (d) pest attacks

However, each broomrape species has its specific host range (Table 2). For example, P. aegyptiaca and P. ramosa have broad host ranges within different Brassicaceae, Cannabaceae, Cucurbitaceae, Fabaceae, and Solanaceae (Brault et al. 2007; Parker 2009; Gibot-Leclerc et al. 2015). Conversely, O. cumana is an obligate parasite of the one sunflower species (Rubiales 2018). Diversity among broomrape populations is closely studied in many countries such as Tunisia, Spain, Turkey for O. cumana (Malek et al. 2017; Jebri et al. 2018), and in France for P. ramosa (Le Corre et al. 2014; Stojanova et al. 2019). Broomrape species are genetically diverse owing to their mating systems and migration strategy favored by the use of contaminated machinery or seedlings (Satovic et al. 2009).

This genetic diversity often implies distinguishing groups with specific traits, e.g., virulence. Different populations of a given species may have host preferences (Benharrat et al. 2005; Brault et al. 2007; Le Corre et al. 2014). These populations have been referred to as races or pathovars, and they result from broomrape adaptation to their hosts. For instance, branched broomrape ( $P$. ramosa) has a broad host range, but host preferences have been highlighted by sampling and genotyping $P$. ramosa populations in European countries. Genetic analysis of $P$. ramosa populations has confirmed the existence of different pathovars (Benharrat et al. 2005; Brault 
et al. 2007; Le Corre et al. 2014; Schneider et al. 2016; Stojanova et al. 2019). Cross infestation assays have showed great specificity of the broomrape cycle for its host's cycle (Gibot-Leclerc et al. 2013; Stojanova et al. 2019). Thus, generalist pathovars that specialize for particular hosts to improve their infestation and reproduction success are often evidenced (Gibot-Leclerc et al. 2012; Malek et al. 2017). It is commonly assumed that branched broomrape was first a generalist parasite that specialized for surrounding crops, based on the synchronization of its cycle with its host cycle. This suggests an evolutionary process (Westwood et al. 2010; Schneider et al. 2016). However, a specialist parasite can also expand its host range following host-induced selection (Satovic et al. 2009): a new race of $O$. cumana recently identified in Israel infests not only sunflower but also tomato crops (Dor et al. 2020). These adaptations seem to occur rapidly when broomrapes settle in croplands, and are a serious agricultural issue. As the parasite and host plant life cycles overlap, two main underground and aerial phases have been described in the parasite cycle (GibotLeclerc et al. 2012; Delavault 2015). Broomrape specialization probably occurs at the first stage of the cycle, i.e., the underground contact between broomrape seeds and host plant root exudates (Fernández-Aparicio et al. 2011; Gibot-Leclerc et al. 2016; Perronne et al. 2017).

The emergence of new broomrape races raises the question of broomrape evolution. Broomrapes seem to quickly and easily adapt to their environment. Therefore, their populations should be carefully monitored and their expansion checked to avoid new infestations in new croplands. Herbicides are considered with caution because broomrapes may develop resistance genes. Moreover, the interaction between broomrapes and their different host plant species can lead to more or less specialization and to the emergence of races/pathovars of even local populations on which the effectiveness of general or specific control methods is unknown. Studies on the specific traits of broomrape races are still missing and are needed to control them.

\subsection{Strigolactones: the first contact}

The broomrape cycle starts with specific interactions. Seeds need an external signal from the host to germinate (Fig. 2). The most studied molecules involved in parasitic seed germination are strigolactones, discovered in cotton extract in 1966 (Cook et al. 1966). Since their discovery, these hormones have been studied through different approaches: chemistry, molecular biology, metabolomics, and ecology (Zwanenburg and Pospíšil 2013; Brun et al. 2018; Tsuchiya 2018; Yao et al. 2018). More than ten molecules have been isolated from natural plant exudates, and today synthetic strigolactones are produced daily for research purposes. These strigolactone analogs are called GR compounds (GR5, GR24 or GR27) (Mangnus et al. 1992; Vurro et al. 2016).
Scientists first focused on the effects of strigolactones on parasitic seeds, but these hormones also have a direct effect on the plant itself. Strigolactone production plays a role in overall plant development and in functions like growth. They inhibit axillary bud growth by acting locally in the concerned organ and/or by modulating auxin transport (Gomez-Roldan et al. 2008; Crawford et al. 2010). When strigolactones are released in the rhizosphere, they act as a signal for symbionts like fungi. Therefore, strigolactones also enhance symbiosis with root arbuscular mycorrhizal (AM) fungi (Akiyama et al. 2005). Furthermore, endogenous strigolactones positively induce the Rhizobium-legume symbiosis (Soto et al. 2010). In that case, they do not act as signal molecules but rather influence the plant itself to improve symbiosis (Foo and Davies 2011). Other studies also support the idea that root nodulation is positively regulated by strigolactones (Foo and Davies 2011; McAdam et al. 2017).

Strigolactones are hormones perceived as germination signals by broomrape seeds (Flematti et al. 2016). Receptors have been identified in obligate parasites such as Striga $s p$. and Orobanche sp. (Conn et al. 2015; Khosla and Nelson 2016). Protein D14 and its homolog KAI2 from Orobanchaceae parasites bind to and hydrolyze strigolactones (Bürger and Chory 2020). This reaction leads to the germination of parasitic seeds towards their host through still unknown processes (Brun et al. 2018). Like a few other parasitic plant families, Orobanchaceae need signaling cues from potential host roots to germinate (Stewart and Press 1990). Because strigolactone biosynthesis is important, its chemical structure, composition, production, and specificity to parasitic seeds have been deciphered (Brun et al. 2018; Wang and Bouwmeester 2018). The main structure of strigolactones includes four rings (A, B, C, and D) and an enol ether double bond between rings $\mathrm{C}$ and $\mathrm{D}$. Parasitic seeds and AM fungi harbor receptors for these molecules. Modifications of the ring structure decrease both seed germination and AM branching, while structural changes in the double bond influence seed germination but not AM branching (Akiyama et al. 2010). Furthermore, their recognition can be very specific. Striga gesnerioides and some Orobanche and Phelipanche species only germinate in the presence of their host-specific strigolactones; in these cases, synthetic GR24 is not an effective germination stimulant (Fernández-Aparicio et al. 2011; Zwanenburg et al. 2013). This intriguing ability to capture a host-specific signal molecule is a strong evolutionary trait showing the dependency of parasitic plants on their host (Wang and Bouwmeester 2018). Evolution has probably played a role in parasitic seed susceptibility towards these molecules. As parasitic plants are angiosperms, they probably also once had to produce strigolactones that are important phytohormones for the reasons cited above (abiotic stress response, symbiosis, growth...). Consequently, they certainly have these molecules "in memory," but probably stopped 
producing them during the co-evolutionary process to use the phytohormones abundantly produced by neighboring plants. This could explain why they parasitize the plants that produce the same strigolactones as they once did, because they are those that best meet their needs. They are now using these strigolactones against their host (Westwood et al. 2010). In addition, they can recognize their host plant even if the molecule is present under different chemical configurations (Wang and Bouwmeester 2018). The diversity of these molecules suggests an evolutionary adaptation of the parasitic plant to detect nearby roots (Brun et al. 2018). It makes the crosstalk between broomrape seeds and germination stimulants particularly complex, including the transport of germination stimulants into broomrape seeds. It provides different alternatives to seeds for germinating, but also makes this process difficult for farmers to control. Strigolactone exudation might be adjusted by a given host cultivar and regulate broomrape development (Yoneyama et al. 2015). This may seem difficult because strigolactones are phytohormones essential for the plant metabolism, but also signal molecules involved in the crosstalk between plants and microorganisms, including mycorrhizae. In another hypothesis, strigolactone signaling pathways and receptors regulate the broomrape seed clock (Aliche et al.
2020; Bürger and Chory 2020). It would be of interest to compare the different receptor structures and specificities of symbiotic fungi and parasitic plants to better outline the impact of strigolactones. However, molecular signaling does not stop here; the transport of germination stimulants into broomrape seeds also plays a key role.

\subsection{Specificity of the interactions with the host plant}

The biological cycle of epirhizal parasites is usually composed of two distinct phases, i.e., an underground phase and an aboveground/aerial phase (Gibot-Leclerc et al. 2012; Delavault 2015).

The first, underground phase is initiated by seed germination and goes on with fixation on host roots and penetration into host tissues. An absorption system called a haustorium develops concomitantly (Kuijt 1969). The seeds persist in the soil for 12 to 20 years (Fig. 3). Because of their very small size $(200-400 \mu \mathrm{m})$, they are easily dispersed by wind, water, or animals. There is no report of important granivory of broomrape seeds (Heide-Jørgensen 2008; Joel 2013). However, despite the lack of articles on the subject, it is difficult to rule out interactions between soil microfauna and broomrape seeds as

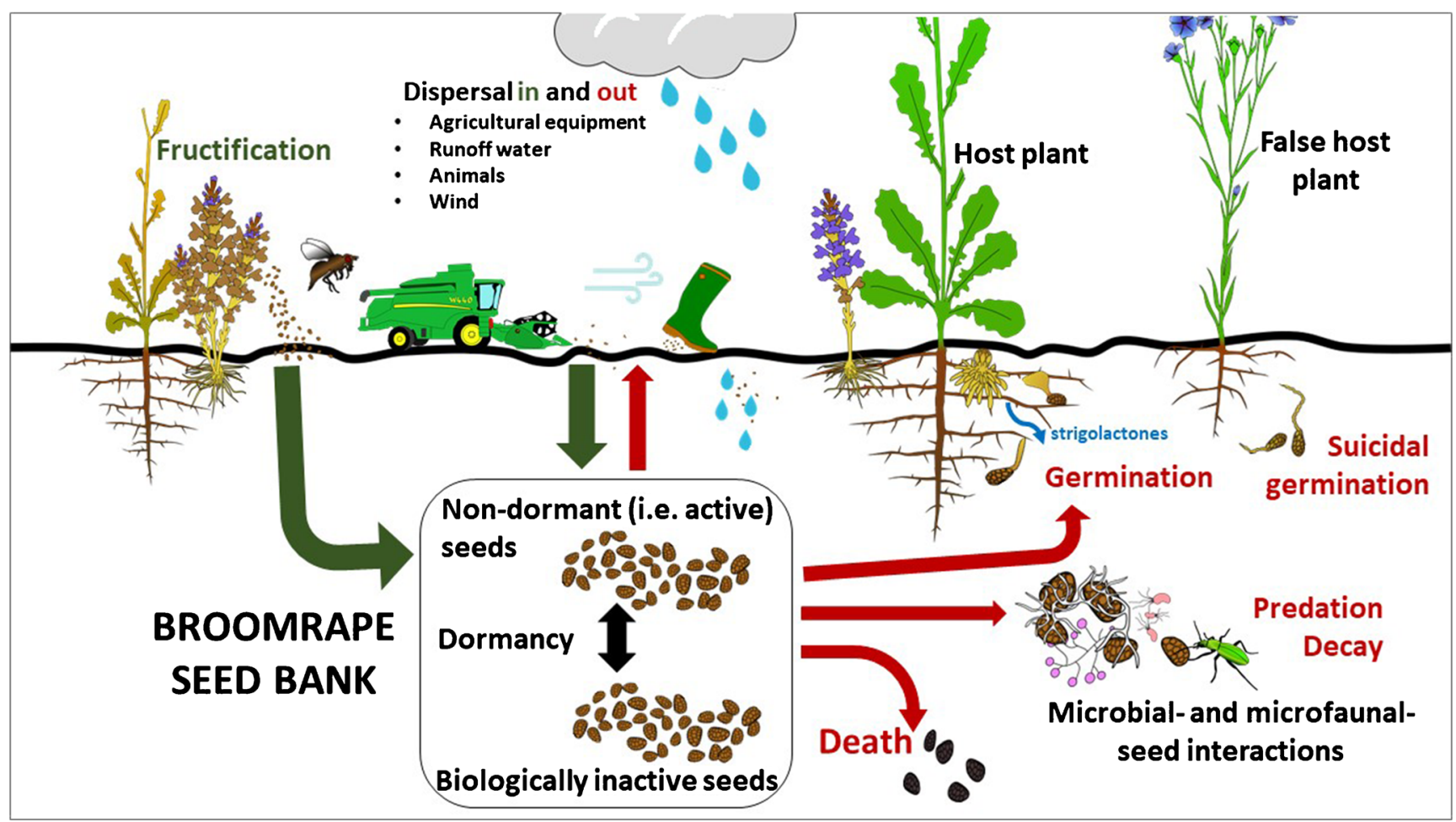

Fig. 3 Balance of broomrape soil seed bank inputs and outputs affecting the broomrape population dynamics in a plot. The broomrape seed bank consists of biologically active seeds and biologically inactive seeds (or dormant seeds). The former are viable seeds that germinate under favorable environmental conditions while dormant seeds have a slowed metabolism and can persist in the soil for more than a decade. Seeds can change from dormant to non-dormant status and vice versa several times during their persistence in the soil. This seed bank is characterized by inputs mainly linked to broomrape fructification and outputs mainly linked to the germination of seeds and their natural mortality due to aging as well as the action of predators and other decomposing microorganisms. Other drivers such as agricultural practices, human and animal movements, and meteorological factors participate in the dispersal of seeds and contribute to the dynamics of the seed bank 
for most weed seeds (Frei et al. 2019). Seed shape, size, and testa micromorphology are potential traits that can be used to discriminate different species, countries, or populations. However, geographic origin and race have no significant effect on seed phenotypic traits (Krupp et al. 2015). After a conditioning period, seeds nearby roots are ready to germinate in response to specific signal molecules released by the host plant in its rhizosphere (Stewart and Press 1990; Penuelas and Llusia 2004). These molecules are plant hormones or secondary metabolites needed for the development and protection of the plant (Liu and Brettell 2019). Haustorium development is critical for successful infestation by the parasitic plant. Its formation includes initiation, penetration, and vascularization. It is induced by the effect of host plant allelochemicals on germinating seeds, which increases parasite aggressiveness (Goyet et al. 2017; Kokla and Melnyk 2018). Thus, both host and parasite developmental processes are key for haustorium formation (Yoshida et al. 2016; Kokla and Melnyk 2018). The haustorium develops from changes in the growth and development of specific cells of the radicle. This allows for (1) complete attachment of the parasitic weed to the host plant, and (2) water and nutrient transfer from the host to the parasite (Yoshida et al. 2016; Kokla and Melnyk 2018). Connection to vascular tissues allows the parasite to extract nutrients and water from its host. However, trades of diverse hormones, RNAs, and viruses have been observed between the host and the parasite. Exchanges are bidirectional, assuming that the parasitic plant and the host are constantly communicating as long as they are connected through the haustorium. High rates of exchanged RNAs reveal an important interaction between the host and the parasite at this stage. Diverse molecules are conveyed through the haustorium. mRNA exchanges suggest that the host plant tries to regulate the parasitic plant using mRNAs (Leblanc et al. 2012; Shahid et al. 2018). Parasite growth continues with the formation of adventitious roots around host roots. Broomrape roots can develop secondary haustoria that will provide stable anchoring for future achlorophyllous stems (Joel 2009).

The aerial phase of the broomrape cycle starts with stem emergence out of the soil. Branched floral scapes develop blue/violet flowers; one floral scape can produce 250,000 seeds that exponentially increase the seed bank in already infested soil (Fig. 3) (Gibot-Leclerc et al. 2012). The phenology of each parasite is successfully adapted to that of its host to maximize competition for resource allocation against the host reproductive sinks. Besides, once broomrape has emerged out of the soil, it is already settled on its host, hence great difficulty in stopping infestation. Very little information is available on the aerial phase of broomrape because successful infestation relies on haustorium formation which is the beginning of the parasitic stage. This step is actually triggered by a cytokinin signal in the rhizosphere (Goyet et al. 2017; Billard et al. 2020). For example, P. ramosa has specific receptors to rapeseed cytokinins to induce haustorium formation. This implies another molecular crosstalk between host roots and germinated parasitic seeds. However, we still do not know how specific the crosstalk between broomrape receptors and rapeseed exudates is. Studies should now focus on the broomrape response to germination stimulants and cytokinins from the host plant. The importance of these two signals must be measured to adapt the control strategy against broomrape. Stimulation of germination may be more crucial for the parasitic attack. Or the combination of germination stimulants and cytokinin exudation may lead to successful parasite establishment. The next point is the host plant's reaction to the parasite: the host plant sends signals that are caught by the wrong recipient, but it may defend itself.

\subsection{Plant defense reactions}

Host plants respond to infestation with different resistance mechanisms. Depending on the time needed for the response, the host plant can stop the parasitic plant at different stages of the infestation process: before germination of nearby seeds, or before haustorium formation, or during parasite growth (Yoshida and Shirasu 2009; Yoder and Scholes 2010). Host plants have defensive mechanisms (mechanical barriers), and also offensive mechanisms (metabolite production) to protect themselves from nearby parasitic plants.

As means of defense, some host plants reduce their root exudate production or produce inhibitors. By decreasing strigolactone production, they stimulate germination of nearby seeds less and can inhibit haustorium initiation (EchevarriaZomeno et al. 2006; Gobena et al. 2017). If seeds germinate and reach a root, host plants can modify the cell walls of their roots to block haustorium penetration (Yoshida and Shirasu 2009; Lewis et al. 2010). For example, the hypersensitive response in tomato prevents infestation by Cuscuta reflexa, an epiphytic Convolvulaceae, by restructuring the tomato cell wall (Lee and Jernstedt 2013). The haustorium cannot penetrate the tomato cortex because adjacent tissues are necrotized and the hypodermis is reinforced by phenylpropanoids (Albert et al. 2004; Kaiser et al. 2015). The mechanisms underlying this physical barrier are still poorly known, but this hypersensitive response is species-specific and is easily overcome by other Cuscuta species. Host plants that activate a necrotizing process suffer from this cost but avoid any attachment and development risk when infestation is detected ( $\mathrm{Li}$ and Timko 2009). In addition, alteration of the cell wall integrity sensed by the host plant is a signal for activating other innate defense responses (see below).

Once infestation has started, the host produces stress metabolites such as abscisic acid (ABA), jasmonic acid (JA), or salicylic acid (SA) to fight infestation or kill the parasite. If infestation is completed, parasitic plants act as a stress factor for the host. For instance, nutrient and water uptake by the 
parasite leads to a drought stress for the host plant (Hegenauer et al. 2017). Production of auxin and other enzymes participates in this plant-plant interaction (Albert et al. 2004). Then, the host plant may respond with other specific molecules targeted against the parasite. Sunflower expresses a defense gene-HaDefl-that encodes a potential lethal molecule for Orobanche radicles. The mode of action of this molecule and its biosynthesis are poorly understood since it is usually active against fungal pathogens (de Zélicourt et al. 2007). Resistant rice cultivars seem to have more pathogenesis-related proteins than susceptible ones. Functional genes are downregulated in susceptible cultivars (Swarbrick et al. 2008; Yoder and Scholes 2010). Therefore, gene expression could be a relevant parameter in the selection of resistant host cultivars (Gurney et al. 2006; Jamil et al. 2011).

The lack of effective resistance mechanisms may be explained by the dual nature of broomrapes, which are parasites and plants. Their infestation has been compared to successful grafting (Westwood 2013; Krupp et al. 2019). Plant grafting requires cellular and vascular connections too. However, grafting can only occur between two related species, while parasitic plants can graft themselves onto phylogenetically distant species (Melnyk and Meyerowitz 2015). Comparing the attachment of parasitic plants to successful grafting could explain how the parasite overcomes the host's recognition barriers (Leblanc et al. 2012). The next step would be to find effective resistance among cultivars. Overall, host responses are not specific to parasitic plants and not fully effective. They resemble reactions against pathogens and pests (Westwood et al. 2010; Hegenauer et al. 2017). That is why combining resistance mechanisms may be more appropriate to regulate broomrape. For instance, Louarn et al. (2016) successfully used a QTL mapping approach to identify sunflower resistance to broomrape at different stages (early attachment, young tubercle, shoot emergence).

Knowing the specificity of the parasitic plant, host plant interaction is required but not sufficient to set up broomrape control methods in croplands. In fact, parasitic plants and more particularly Orobanche and their hosts are subject to environmental factors or regulatory mechanisms that can directly or indirectly affect their development or even their survival. The intensity of biotic regulatory mechanisms is generally modulated by the intensity of abiotic regulatory mechanisms. This is true for all organisms, including broomrapes.

\section{Broomrape regulation mechanisms}

\subsection{Background}

Given their life cycle, broomrapes seem to have adopted a colonization strategy to ensure their propagation and survival (Fig. 3; Gaba et al. 2017). They indeed produce millions of tiny seeds released at a variable distance from the mother floral scape. The chances of survival of these seeds are probably not the same for all because of various biotic and abiotic regulation factors (Fig. 2). A small proportion will remain in the rhizosphere of the future host plant where they will germinate, stimulated by the root exudates of the host plant. Some of them will settle and infest the host plant; the others will be killed by plant-derived allelochemicals (Cimmino et al. 2018; Qasem and Issa 2018). Seeds outside the rhizosphere are dormant, and most of them will survive for several years in the soil and contribute to what is called the weed seed bank (Haring and Flessner 2018; Pointurier et al. 2019). In parallel, a host of small animals and diversified microorganisms also lives in the soil. They interact with one another and form complex interaction networks. For instance, earthworms or carabids consume weed seeds, including seeds of parasitic plants, and thus participate in the regulation of their populations (Frei et al. 2019). In parallel, microbial relationships range from intraspecific to interspecific interactions, and from simple short-term interactions to intricate long-term ones (Moënne-Loccoz et al. 2015). For example, the decomposition of plant residues by microorganisms leads to the production of lethal metabolites for weed seeds including broomrape seeds (Li et al. 2019; Xiao et al. 2020). Microbial activities also involve direct interactions with seeds that can constitute niches for some microorganisms or provide trophic resources for others, resulting in a pathogenic interaction. However, specificity has not yet been shown (Pollard 2018; Rodriguez et al. 2018). Most of soil-borne pathogens are adapted to grow and survive in the bulk soil, but the place where the pathogen establishes a parasitic relationship with the plant is the rhizosphere. Finally, parasitic plants pose enough problems in agriculture for humans to try to regulate or even control their expansion by stimulating biotic factors associated with agricultural practices. In an agroecological context, it is important to (1) identify the different drivers of broomrape regulation, and (2) know their role and their relative importance, so as to exacerbate these interactions (alone or combined), relatively to other components of the agroecosystem and the environment.

\subsection{Regulation of broomrape by allelopathy}

Allelopathy is a form of amensalism in which some organisms are inhibited or destroyed and the others are unaffected by the release of metabolites called allelochemicals into the environment (Trezzi et al. 2016; Scavo et al. 2018). Many allelochemicals present in the soil are produced by plants and microorganisms or result from the decomposition of plant residues by microorganisms (Xiao et al. 2020). The impact of allelochemicals depends on many factors: soil factors, but also meteorological and plant factors. All these parameters can disrupt the allelochemical balance in the soil solution (Scavo et al. 2019). In broomrape studies, rhizosphere allelochemicals have been studied mostly for their direct effect 
on broomrape seeds (Cimmino et al. 2018). These molecules (e.g., strigolactones produced by putative host plants) have a stimulating effect on broomrape germination; in this case, allelopathy has a negative boomerang effect on the producing plant (Flematti et al. 2016). Interestingly, the molecules that stimulate parasitic plant germination can be the same as those that inhibit other weeds (Rial et al. 2020). Once again, this difference highlights the special case of parasitic plants among weeds.

When it comes to metabolites produced by non-host plants, this stimulation of germination results in broomrape suicidal germination (Dong et al. 2012; Chai et al. 2015; Ye et al. 2016). However, many allelochemicals negatively affect the germination and growth of susceptible seeds and plants including broomrapes (Evidente et al. 2007; Cimmino et al. 2014). For example, allelochemicals produced by soil microorganisms, e.g., cytochalasins and sphaeropsidin A, inhibit broomrape germination and radicle development (Cimmino et al. 2018). Many other molecules such as proteins, peptides, or nucleic acids are secreted by soil microorganisms and potentially affect broomrapes. These complex extracellular secretions have attracted scientific interest in a new field called plant-fungal secretomics (Vincent et al. 2020). The study of plant-fungal interactions obviously takes into account this communication mechanism via molecules secreted in the extracellular space. However, little is known today about the broomrape secretome and its beneficial or pathogenic interactions with soil microorganisms.

Therefore, allelopathy clearly appears to be one of the natural factors regulating broomrape in an integrated pest management system. The complexity of the direct or indirect impacts of allelochemicals on parasitic plants makes their use very tedious in a control strategy. Further studies are still needed to master the allelochemicals of a natural interacting network, i.e., the rhizosphere. However, practical applications for sustainable weed management are already available in lowinput or no-input agricultural systems (Scavo and Mauromicale 2020). These techniques may be used for parasitic weeds while taking their specific traits into account. Besides, aerial allelochemicals of broomrape have hardly been studied, even if they produce a unique blend of volatile organic compounds (VOCs) in their floral scapes, like all other plants. These blends are species-characteristic, and their phylogenetic patterns revealed broomrape's life history (Tóth et al. 2016). Further studies of broomrape aerial allelochemicals would improve our knowledge of its evolution and maybe answer other questions on its ecology: flowers and stems emit VOCs that act as signals for other organisms (plants, insects...) and are produced by a functional microbiota.

\subsection{Regulation of broomrape by pests}

Interactions between animals and parasitic plants are very diverse and complex. Broomrapes can be attacked by pests such as Phytomyza orobanchia, and by more or less specific pathogens (Klein and Kroschel 2002; Fernández-Aparicio et al. 2016). These interactions can be direct or indirect, positive or negative for one or the other or both, they can affect the parasitized host plant or not, which in turn can disrupt parasitic plant-animal interactions. The host plant-parasitic plant interaction inversely determines pest growth and development. Yet, even if the chemical composition of the parasitic plant is not determined by that of the host plant, its palatability for pests can be influenced (Schädler et al. 2005). Many species of herbivores, like ants, caterpillars, mammals, and butterflies, may interact with parasitic plants, especially in natural communities (Press and Phoenix 2005; Heide-Jørgensen 2008). Parasitic plant herbivores have been observed in natural communities. As broomrape studies are mainly focused on infested agricultural plots where insect communities are generally less diverse than in natural ecosystems (Thiele 1977), this can explain this information gap. Furthermore, broomrapes may be less attractive to herbivores and granivores because they lack leaves and green organs, which can be visual signals for herbivores seeking food or shelter. Broomrape seeds are probably too small to be predated by mammals or insects. This apparent lack of interaction may hide a repellent effect of broomrape towards animals. For instance, the parasitic Convolvulaceae C. reflexa produces VOCs to deter insects (Srivastava and Jaiswal 1990). Conversely, attracting disseminators improves parasitic plant fitness by spreading their seeds and increasing their reproduction rate. Parasitic plants use the same strategies as other angiosperms to attract their pollinators and disseminators (colors, odors, texture, nectar...). For example, the holoparasite Rafflesia sp. (Rafflesiaceae) produces very large and fragrant flowers to attract blow flies (Heide-Jørgensen 2008).

Parasitic plants are also a specialized habitat for insects to live or reproduce in. For instance, the holoparasite Thonningia sanguinea (Balanophoraceae) is a favorable brood-site for a blood-feeding fly in Africa (Goto et al. 2012). No such interaction has been described so far with broomrape VOCs, although Orobanchaceae produce many VOCs (Tóth et al. 2016). However, it is difficult to imagine that broomrapes do not interact with any insect, bird, or other herbivorous organism. Studies on hemiparasites show that some (e.g., Cassytha filiformis (Lauraceae)) negatively impact gallforming insects co-occurring on a shared primary host plant (Egan et al. 2018), or others (e.g., mistletoe) cleverly use insects, birds, or small mammals to disseminate their seeds (Mellado and Zamora 2016; Van Halder et al. 2019). Others again mimic their host plant to escape possible predators (Heide-Jørgensen 2008). Thus, special attention should be focused on broomrapes to decipher their interactions with the fauna. The way pests regulate broomrape populations is poorly documented, but parasitic plants have obviously adapted to benefit from the services of animals and ensure the dissemination of their seeds. 


\subsection{Regulation of broomrape by soil-borne microorganisms}

The colonization strategy developed by broomrape pays off: apart from the seeds that germinate in the host plant (or sometimes non-host plant) rhizosphere and fail to infect the plant, the thousands of seeds produced by a single floral scape can either give birth to new plants (and a new supply of seeds) or survive in bulk soil, awaiting the next infection. However, whether in the rhizosphere or bulk soil, broomrape seeds have to face the soil biota. The rhizosphere is indeed the infection court for parasitic plants. It is also a hotspot of microbial interactions: exudates released by plant roots are a main food source for microorganisms and a driver of their population density and activity (Raaijmakers et al. 2009). The rhizosphere hosts organisms that have neutral/beneficial effects on plants, but also deleterious effects. These are pathogenic fungi, oomycetes, bacteria, and nematodes. Observations about cultivated plants are valid for weeds, including parasitic plants. These play a particular role since they parasitize the plants thanks to which their seeds can germinate and achieve infestation, while facing beneficial and pathogenic microorganisms (Sauerborn et al. 2007; Runyon et al. 2009; Chen et al. 2016). Fungi belonging the genus Fusarium and the species $F$. oxysporum, $F$. solani, $F$. camptoceras, $F$. chlamydosporum, $F$. lateritium, $F$. arthrosporioides, and F. verticillioides, but also Aspergillus alliaceaus and Talaromyces trachyspermus have been isolated from broomrape, and their pathogenicity has been characterized (Amsellem et al. 2001b; Boari and Vurro 2004; Dor and Hershenhorn 2009; Aybeke et al. 2015; Hemmati and Gholizadeh 2019). Unfortunately, the pathogenic activity of these many isolates has never been quantified in situ, and regulation of broomrapes by pathogenic fungi is difficult to highlight. Conversely, maize infestations by the witchweed Striga hermonthica in Kenya significantly decreased following purposeful inoculation of the host plant rhizosphere with a $F$. oxysporum strain. Therefore, pathogenic fungi in sufficient density can actively participate in the regulation of parasitic plants (Nzioki et al. 2016). However, given the huge number of seeds likely to parasitize the roots of host plants, some kind of regulation undoubtedly curbs infestation, which should be much higher than observed. This interaction can also be seen as a self-regulating mechanism implemented by broomrapes. A parasite has indeed no interest in killing its host to complete its cycle. Thus, the pathogenic activity of fungi on broomrapes allows host plants to survive till broomrape flowering and seed release by regulating broomrape infestation. Fungal attacks can occur at several infestation stages. First, the fungus can inhibit seed germination or destroy the radicle. Second, the fungus can necrotize the broomrape tubercle after attachment to the host roots. These two phases are the most effective ones. Third, the fungus can also infest and damage the underground stem and the flower stem, but this process is slower.

The proportion of seeds from a same flower stalk that will ultimately complete the broomrape cycle is still unknown. Despite a very slow metabolism, many seeds will probably die from exhaustion after a few decades in bulk soil (Fig. 3). They can also constitute food resources for saprophytic microorganisms regardless of any specific pathogenicity relationship. Soil fungi contribute to some of the losses in the weed seed bank thanks to their enzymatic arsenal (Mitschunas et al. 2009; Ullrich et al. 2011; Fuerst et al. 2014). Moreover, fungal or bacterial phytotoxins have been detected in the spermosphere of cultivated seeds (Schiltz et al. 2015); although no information is available on their impact on broomrape seeds, some of these metabolites may also alter broomrape seed survival. Therefore, although demonstrations are still needed, soil-borne fungi most probably regulate part of the broomrape seed bank in bulk soil and in rhizosphere soil (Fig. 3). This regulation could be positive for broomrape, since a core microbiota was identified in broomrape seeds from a same host plant (Huet et al. 2020). This core microbiota might be involved in broomrape specialization for its host. This implies that microorganisms associated to broomrape seeds would enhance host plant infestation. Host plant rhizosphere pathogens might also stimulate the production of germination-inducing molecules (strigolactones, glucosinolates, etc.) and thus promote infestation by broomrapes. However, the outcome is uncertain because pathogens and parasitic plants compete for the same host plant, which may not allow broomrape to complete its cycle because of concomitant fungal disease. Microorganisms are potential intermediate messengers in the host plant-parasitic plant interactions. Various secretions ranging from complex polymers (proteins) to small compounds (phytohormones) mediate plant-fungal interactions in the soil. Therefore, the many different compounds found in the rhizosphere constitute plant or fungal secretomes (Vincent et al. 2020). To optimize broomrape regulation by these natural interactions, further research is needed on microorganism communities in the broomrape rhizosphere and on the broomrape secretome.

\subsection{Regulation, unless it be control attempts, of broomrape by human activities}

Current control methods of Orobanchaceae are not $100 \%$ efficient. Despite numerous efforts, crop genetic selection does not provide resistant cultivars in infested areas (Pérezde-Luque et al. 2009). Herbicides have showed their limitations: reduced effectiveness, emergence of resistant individuals, and a negative connotation as to their impact on the environment and human health (van Bruggen et al. 2018; Vila-Aiub 2019). The agroecological transition requires a real 
decrease if not a total ban of chemicals to promote the implementation of alternative control methods of parasitic weeds. Unfortunately, many of them have not proved, or not yet fully proved, successful. For instance, mechanical weeding is not possible because most of the damage to the host plant is already effective when broomrape emerges, and it is difficult to get in the fields at that stage of crop development (FernándezAparicio et al. 2016). However, in non-intensive systems like the coastal savanna zone of Ghana, farmers tried to control Striga on sorghum, millet, maize, rice, and cowpea by hand weeding. This practice is tedious, and requires one to three passages in the plots to contain the parasitic populations (Aflakpui et al. 2008).

One possible solution to reduce the tremendous seed bank is the use of catch crop species, which are host plants very susceptible to parasitic plants (Fernández-Aparicio et al. 2011; Aksoy et al. 2016; Aly and Dubey 2014). They are planted to reduce the seed bank by inducing parasitic seed germination and attachment, and then they are destroyed mechanically before broomrape reaches the seeding stage. In this scenario, the seeds will die because they cannot get the resources required for them to develop. Soybean or cowpea is a good trap crop in maize crops. They can increase the maize yield in 1 year, with hardly any detectable Striga hermonthica in the field (Gbèhounou and Adango 2003). In the same line, the seed bank of $O$. aegyptiaca can be reduced by up to $20 \%$ thanks to a catch crop (Acharya et al. 2002).

Cultivation of non-host plants producing phytohormones (including strigolactones) leads to suicidal germination of broomrape seeds (Qasem 2019). Analogs of strigolactones have been tested in laboratory for their ability to induce seed germination, and some have been proposed to control P. ramosa (Takahashi and Asami 2018; Zwanenburg and Blanco-Ania 2018). Suicidal germination of broomrape seeds was induced by sprinkling a solution of formulated strigolactones in the field at least 15 days before planting tobacco; the number of infested host plants was significantly reduced (Zwanenburg et al. 2016). However, no follow-up was given to this trial, probably because natural strigolactones are not stable molecules in natural conditions and are difficult to mass produce (Zwanenburg and Pospíšil 2013).

A certain number of agricultural practices participate in the reduction of the soil weed seed bank (Scavo and Mauromicale 2020). For example, diversifying rotations avoids the chronic emergence and invasive multiplication of the same invasive species. Plowing buries seeds and prevents them from germinating in competition with the crops of interest. These two approaches are often combined (Haring and Flessner 2018). However, their effectiveness is all the greater as seed longevity is low and seeds are localized at shallow depth. Unfortunately, broomrape seeds have a lifespan of more than 10 years, and plowing in fine facilitates and homogenizes their distribution across the different soil strata (Scherner et al.
2016). Plowing is therefore only a short-term solution. Nevertheless, more diverse rotations avoid increasing the broomrape seed bank, and it is wise to combine them with the incorporation of catch crops in the rotation system. Finally, solarization has been successfully used to reduce the orobanche seed bank in tomato crops (Mauromicale et al. 2005; Mauro et al. 2015). As broomrapes, and more particularly $P$. ramosa can also parasitize weeds likely to maintain the seed bank (Gibot-Leclerc et al. 2003), the efficiency of these different agricultural practices results from their combination within an integrated weed management strategy.

Attachment of broomrape seeds to host plant roots is very susceptible to the presence of amino acids. Asparagine favors P. aegyptiaca attachment to Arabidopsis thaliana, whereas methionine and to a lesser extent tryptophan and lysine inhibit O. minor attachment to red clover (Vurro et al. 2006; Fernández-Aparicio et al. 2017; Clermont et al. 2019). However, amending cultivated fields with amino acid solutions to control $O$. minor is not realistic: besides their cost, amino acids can leach towards aquifers and pollute them. Conversely, the contribution of microorganisms or the stimulation of indigenous microorganisms producing methionine, tryptophan, and lysine in the host plant rhizosphere would be an interesting means of limiting broomrape infestation.

These few examples show that it should be possible to intervene on one of the stages of the broomrape development cycle through various agricultural practices. However, these practices are not all applicable in the field, either for economic and environmental reasons or for reasons of compatibility with the cropping system. Furthermore, these empirical-yet commendable - approaches only partly reduce the infectious potential of broomrapes in a plot. This is why we should consider a coordinated combination of all these approaches within an agroecological framework to reach a more convincing result.

\subsection{Biocontrol? Yes, but in what way?}

Biocontrol often appears as the alternative method when all the other methods have failed. There clearly exists a potential to be explored and implemented, but it should be designed as a complementary method to all the methods mentioned above. Microorganisms capable of infesting parasitic plants have been isolated and characterized for their pathogenicity towards broomrape or witchweed. For instance, Streptomyces bacterial strains reduced the number of $O$. cumana tubercles by almost $50 \%$ (Chen et al. 2016). In the same line, Azospirillum strains and Bacillus/Pseudomonas strains inhibited radicle elongation of germinating seeds of $S$. hermonthica and O. aegyptiaca/O. cernua, respectively (Miché et al. 2000; Barghouthi and Salman 2010; Kruh et al. 2017). Furthermore, soil-borne fungi including many Fusarium species have also been isolated and tested for their 
potential mycoherbicide activity towards parasitic plants. The modes of action revealed by in vitro tests concern most broomrape developmental stages: seed germination inhibition notably via the production of metabolites such as fusaric acid or trichothecenes, necrosis and rot of tubercles, or reduced shoot growth (Boari and Vurro 2004; Dor et al. 2007). In pot tests, the number of tubercles formed and the number and dry mass of emerging shoots were reduced, while the dry mass of the host plant increased almost up to that of the control (Thomas et al. 1999; Boari and Vurro 2004; MüllerStöver et al. 2008). In general, each strain was rather effective on one broomrape species or group of species, and to a lesser extent on the others; however, it is difficult to talk about specificity of the interaction. Nevertheless, a $F$. oxysporum strain was described as $P$. ramosa-specific (Müller-Stöver et al. 2008). Two other Fusarium strains were pathogenic to $O$. aegyptiaca, O. cernua, and $P$. ramosa, but not to $O$. cumana (Amsellem et al. 2001b). Another $F$. oxysporum strain isolated from symptomatic broomrape and described as a forma specialis called f. sp. orthoceras was pathogenic to $O$. cumana and $O$. cernua but not to $O$. aegyptiaca (Thomas et al. 1999). Yet, strains of $F$. oxysporum f. sp. strigae have been characterized for their host specificity against Striga species, and one of them is now successfully implemented for biocontrol of maize in the field (Elzein et al. 2008; Nzioki et al. 2016). Surprisingly, the strain is supplied to farmers who multiply the inoculum in rice cooked a few days before sowing. For sowing, farmers put a handful of $F$. oxysporumcolonized rice at the bottom of the hole, then place the maize seed on top of it, and fill the hole with a handful of soil (Nzioki et al. 2016). Paradoxically, despite the high number of promising strains for broomrape biocontrol, none of them is currently marketed (Hershenhorn et al. 2009). Regulations may be a hindrance: besides being effective in a reproducible manner in the environment where it will be introduced, the candidate must meet numerous ecological, ecotoxicological, and health requirements as regards humans and animals (Alabouvette et al. 2006). Meeting these requirements requires costly studies that the market may not cover, especially if it is marginal.

Pathogen inoculation for broomrape control may not be the most appropriate strategy because it is based on the mode(s) of action of a strain/group of strains introduced into an environment contaminated by broomrape seeds for decades. The law of numbers implies that an infested soil is infested for a very long time (ad vitam eternam?) despite the natural regulatory mechanisms mentioned above, whether they concern seeds or plants. However, certain fields seem less affected than others within a same infested area, and broomrape eruptions occur in clusters in infested fields. The seed bank cannot be definitively located because animals, wind, water, and tillage favor seed distribution across the whole plot and among plots in addition to their invasive propensity (Fig. 3). Moreover, so-far unidentified abiotic or more likely biotic factors inhibit germination, attachment, or/and growth of young belowground shoots. In other words, the activity of functional and taxonomic components of the microbiota could regulate broomrape seed germination locally or at the plot scale. A similar phenomenon called soil suppressiveness to plant disease can occur in the case of plant diseases caused by plant-pathogenic fungi or nematodes (Westphal and Becker 2001; Mazzola 2002; Mendes et al. 2011; Steinberg et al. 2019). In the present case, it would rather be called soil suppressiveness to plant parasitism. Unfortunately, too few studies on the mechanisms of soil suppressiveness to plant parasitism have been conducted to date. Nevertheless, the term "suppressive" has been used for fields where broomrape density is low compared to surrounding fields. Microbiological isolations carried out in these soils have provided candidates for biocontrol, among which one Pseudomonas fluorescens strain (Zermane et al. 2007). “omics" molecular tools and CAZymes (Carbohydrate-Active enZimes database) analyses would allow for a comparative analysis of the microbiomes of suppressive and conducive soils and highlight the regulatory mechanisms of parasitic plant populations in soils (Mendes et al. 2011; Barbi et al. 2014; Lombard et al. 2014; Siegel-Hertz et al. 2018). Given the ecology of broomrapes (a major underground phase) and the large number of seeds (colonization strategy), their biocontrol by one or more strains seems difficult, even if many laboratory results are promising. Biocontrol is encouraged by agricultural policies, with research efforts for successful candidates, and technical institutes and experimental stations carry out tests close to production conditions. Nevertheless, biocontrol still fails to meet the expectations of producers, particularly in the fight against soil-borne pathogens and weeds, including parasitic plants. One of the reasons for this relative failure undoubtedly comes from the fact that we expect strains able to inhibit broomrape seed germination or damage the tissues of the targeted parasitic plant under laboratory conditions to have the same efficiency in environmental conditions. However, environmental conditions are complex, and governed by numerous biotic and abiotic interactions. The introduced strain may not be able to adapt to them, whereas the targeted parasitic plant is adapted. The same applies to the biocontrol of soil-borne plant pathogenic fungi. Therefore, without excluding this approach, biocontrol by conservation, i.e., by stimulating natural regulatory mechanisms, must also be implemented.

Modeling approaches have proved useful for risk assessment of weed population dynamics and cropping system prediction (Holst et al. 2007; Pardo et al. 2010). The dynamic of Egyptian broomrape has been modeled in tomato, carrot, and sunflower crops to optimize herbicide control of the parasitic plant with a decision support system (DSS) (Eizenberg et al. 2012; Cochavi et al. 2016). Other models like PheraSys have been generated for P. ramosa, using biological traits such as 
seed bank and seed production, germination, mortality, and phenology, but also traits of other weeds and crops in a multispecies stand (Colbach et al. 2011; pers. com.). Interactions between broomrape and other weeds are possible in plots, and they must be integrated in future management strategies. Depending on broomrape species, crop plants, and existing weeds, models can predict plot scale broomrape dynamics. Then, a combination of cropping techniques is simulated to limit broomrape infestation. One can also use current international recognized models such as the Agricultural Production Systems sIMulator (APSIM), and add parasitic plants to predict their dynamic (Manschadi et al. 2003). Knowledge on the specific traits of parasitic plants is still scarce. Upcoming models will test different management strategies to design long-term biological control of broomrape using integrated weed management strategies. Field validations will also be important to reach robust predictions. This knowledge will lead to the proposal of agricultural methods favoring regulatory mechanisms within the framework of environmentally friendly and suitable strategies of conservation and sustainable agriculture (Raaijmakers and Mazzola 2016; Steinberg et al. 2019).

\section{Conclusion}

Broomrapes are parasitic weeds with a life cycle closely bound to their host's, and with a major underground stage. Their development mainly depends on interactions with their host but also on their environment. They grow in the rhizosphere where microorganisms, insects, and other plants' roots communicate in a positive, negative, or neutral way. Therefore, broomrapes partake in various biotic and abiotic interactions that can affect their life cycle. Finding a suitable management strategy for each species and crop still remains a challenge. Besides, new methods are currently emerging to achieve current agroecology goals, namely sustainable cropping systems without non-natural inputs. Because of their strategy, broomrapes are durably invasive, and despite the great scientific interest they arouse, limiting the damage they cause to many crops worldwide remains a complex task. Fungal strains have been isolated and characterized for their pathogenicity under laboratory conditions. They are presented as promising candidates for biocontrol, but their field use obviously seems unrealistic in conventional agriculture because broomrapes are bound to be far more abundant than introduced fungal populations. Therefore, biological control of broomrape requires working on an integrated weed management strategy that will combine (1) the various already known regulation mechanisms, (2) those to be known very soon thanks to studies on the functional diversity of soil suppressiveness to parasitic plants, and (3) the use of models exploiting field data as a decision support tool to determine the right cropping system.

We have the main ingredients required for regulating - not eradicating-broomrape populations below a tolerance threshold compatible with the agroecological production of foodstuffs and the survival of broomrapes that, like it or not, are fascinating plants.

Acknowledgements We are grateful to T. Badie for the drawings. We thank Annie Buchwalter for editing English language.

Author contribution Both authors contributed equally to the writing of this review. D.C. provided the pictures and the figures (schema).

Data availability All the data used to write this bibliographic review come from the publications listed in the reference list below.

\section{Declarations}

Conflict of interest The authors declare no conflict of interest.

\section{References}

Abbes Z, Kharrat M, de Tunisie, et al. (2008) Seed germination and tubercle development of Orobanche foetida and Orobanche crenata in presence of different plant species. Tunis J Plant Prot 3:11

Acharya BD, Khattri GB, Chettri MK, Srivastava SC (2002) Effect of Brassica campestris var. toria as a catch crop on Orobanche aegyptiaca seed bank. Crop Prot 21:533-537. https://doi.org/10. 1016/S0261-2194(01)00137-5

Aflakpui GKS, Bolfrey-Arku GE-K, Anchirinah VM et al (2008) Incidence and severity of Striga spp. in the coastal savanna zone of Ghana: results and implications of a formal survey. Outlook Agric 37:219-224. https://doi.org/10.5367/000000008785915548

Ahonsi MO, Berner DK, Emechebe AM et al (2003) Potential of ethylene-producing pseudomonads in combination with effective N2-fixing bradyrhizobial strains as supplements to legume rotation for Striga hermonthica control. Biol Control 28:1-10. https://doi. org/10.1016/S1049-9644(03)00051-3

Akiyama K, Matsuzaki K, Hayashi H (2005) Plant sesquiterpenes induce hyphal branching in arbuscular mycorrhizal fungi. Nature 435:824 827. https://doi.org/10.1038/nature03608

Akiyama K, Ogasawara S, Ito S, Hayashi H (2010) Structural requirements of strigolactones for hyphal branching in AM fungi. Plant Cell Physiol 51:1104-1117. https://doi.org/10.1093/pcp/pcq058

Aksoy E, Arslan ZF, Tetik Ö, Eymirli S (2016) Using the possibilities of some trap, catch and Brassicaceaen crops for controlling crenate broomrape a problem in lentil fields. Int J Plant Prod 10:53-62

Alabouvette C, Olivain C, Steinberg C (2006) Biological control of plant diseases: the European situation. Eur J Plant Pathol 114:329-341. https://doi.org/10.1007/s10658-005-0233-0

Albert M, Werner M, Proksch P et al (2004) The cell wall-modifying xyloglucan endotransglycosylase/hydrolase LeXTH1 is expressed during the defence reaction of tomato against the plant parasite Cuscuta reflexa. Plant Biol 6:402-407. https://doi.org/10.1055/s2004-817959

Aliche EB, Screpanti C, De Mesmaeker A et al (2020) Science and application of strigolactones. New Phytol 227:1001-1011. https:// doi.org/10.1111/nph.16489 
Alla MMN, Shabana YM, Serag MM, Hassan NM, El-Hawary MM (2008) Granular formulation of Fusarium oxysporum for biological control of faba bean and tomato Orobanche. Pest Manag Sci 64: 1237-1249. https://doi.org/10.1002/ps.1625

Aly R, Dubey NK (2014) Weed management for parasitic weeds. In: Chauhan BS, Mahajan G (eds) Recent Advances in Weed Management. Springer, New York, NY, pp 315-345

Amsellem Z, Barghouthi S, Cohen B et al (2001a) Recent advances in the biocontrol of Orobanche (broomrape) species. Biol Control 46:211228

Amsellem Z, Kleifeld Y, Kerenyi Z et al (2001b) Isolation, identification, and activity of mycoherbicidal pathogens from juvenile broomrape plants. Biol Control 21:274-284. https://doi.org/10.1006/bcon. 2001.0934

Aybeke M (2017) Fusarium infection causes genotoxic disorders and antioxidant-based damages in Orobanche spp. Microbiol Res 201: 46-51. https://doi.org/10.1016/j.micres.2017.05.001

Aybeke M, Șen B, Ökten S (2015) Pesta granule trials with Aspergillus alliaceus for the biocontrol of Orobanche spp. Biocontrol Sci Tech 25:803-813. https://doi.org/10.1080/09583157.2015.1018813

Babaei S, Alizadeh H, Jahansouz MR et al (2010) Management of Phelipanche aegyptiaca Pomel. using trap crops in rotation with tomato (Solanum lycopersicom L.). Aust J Crop Sci 4:437-442

Barbi F, Bragalini C, Vallon L et al (2014) PCR primers to study the diversity of expressed fungal genes encoding lignocellulolytic enzymes in soils using high-throughput sequencing. PLoS One 9: e116264. https://doi.org/10.1371/journal.pone.0116264

Barghouthi S, Salman M (2010) Bacterial inhibition of Orobanche aegyptiaca and Orobanche cernua radical elongation. Biocontrol Sci Tech 20:423-435. https://doi.org/10.1080/09583150903340544

Baucom RS (2019) Evolutionary and ecological insights from herbicideresistant weeds: what have we learned about plant adaptation, and what is left to uncover? New Phytol 223:68-82. https://doi.org/10. 1111/nph.15723

Benharrat H, Boulet C, Theodet C, Thalouarn P (2005) Virulence diversity among branched broomrape $(O$. ramosa $\mathrm{L}$.) populations in France. Agron Sustain Dev 25:123-128. https://doi.org/10.1051/ agro:2004059

Berner DK, Williams OA (1998) Germination stimulation of Striga gesnerioides seeds by hosts and nonhosts. Plant Dis 82:12421247. https://doi.org/10.1094/PDIS.1998.82.11.1242

Billard E, Goyet V, Delavault P et al (2020) Cytokinin treated microcalli of Phelipanche ramosa: an efficient model for studying haustorium formation in holoparasitic plants. Plant Cell Tissue Organ Cult 141: 543-553. https://doi.org/10.1007/s11240-020-01813-6

Blaix C, Moonen AC, Dostatny DF et al (2018) Quantification of regulating ecosystem services provided by weeds in annual cropping systems using a systematic map approach. Weed Res 58:151-164. https://doi.org/10.1111/wre.12303

Boari A, Vurro M (2004) Evaluation of Fusarium spp. and other fungi as biological control agents of broomrape (Orobanche ramosa). Biol Control 30:212-219. https://doi.org/10.1016/j.biocontrol.2003.12. 003

Brault M, Betsou F, Jeune B et al (2007) Variability of Orobanche ramosa populations in France as revealed by cross infestations and molecular markers. Environ Exp Bot 61:272-280. https://doi.org/ 10.1016/j.envexpbot.2007.06.009

Brun G, Braem L, Thoiron S et al (2018) Seed germination in parasitic plants: what insights can we expect from strigolactone research? J Exp Bot 69:2265-2280. https://doi.org/10.1093/jxb/erx472

Bürger M, Chory J (2020) The many models of strigolactone signaling. Trends Plant Sci 25:395-405. https://doi.org/10.1016/j.tplants. 2019.12.009

Chai M, Zhu X, Cui H et al (2015) Lily cultivars have allelopathic potential in controlling Orobanche aegyptiaca Persoon. PLoS One 10: e0142811. https://doi.org/10.1371/journal.pone.0142811
Chen J, Xue QH, McErlean CSP et al (2016) Biocontrol potential of the antagonistic microorganism Streptomyces enissocaesilis against Orobanche cumana. BioControl 61:781-791. https://doi.org/10. 1007/s10526-016-9738-z

Cimmino A, Fernández-Aparicio M, Andolfi A et al (2014) Effect of fungal and plant metabolites on broomrapes (Orobanche and Phelipanche spp.) seed germination and radicle growth. J Agric Food Chem 62:10485-10492. https://doi.org/10.1021/jf504609w

Cimmino A, Masi M, Rubiales D et al (2018) Allelopathy for parasitic plant management. Nat Prod Commun 13:1934578X1801300. https://doi.org/10.1177/1934578X1801300307

Cirillo V, Masin R, Maggio A, Zanin G (2018) Crop-weed interactions in saline environments. Eur J Agron 99:51-61. https://doi.org/10. 1016/j.eja.2018.06.009

Clermont K, Wang Y, Liu S et al (2019) Comparative metabolomics of early development of the parasitic plants Phelipanche aegyptiaca and Triphysaria versicolor. Metabolites 9:114. https://doi.org/10. 3390/metabo9060114

Cochavi A, Rubin B, Achdari G, Eizenberg H (2016) Thermal time model for Egyptian broomrape (Phelipanche aegyptiaca) parasitism dynamics in carrot (Daucus carota L.): field validation. Front Plant Sci 7. https://doi.org/10.3389/fpls.2016.01807

Cohen BA (2002) Infection of tubercles of the parasitic weed Orobanche aegyptiaca by mycoherbicidal Fusarium species. Ann Bot 90:567578. https://doi.org/10.1093/aob/mcf238

Colbach N, Abdennebi-Abdemessed N, Gibot-Leclerc S (2011) A preliminary approach for modelling the effects of cropping systems on the dynamics of broomrape (Phelipanche ramosa) in interaction with the non parasitic weed flora. Oilseeds Fats Crops Lipids 18: 39-45. https://doi.org/10.1684/ocl.2011.0360

Conn CE, Bythell-Douglas R, Neumann D et al (2015) Convergent evolution of strigolactone perception enabled host detection in parasitic plants. Science 349:540-543. https://doi.org/10.1126/science. aab1140

Cook CE, Whichard LP, Turner B et al (1966) Germination of witchweed (Striga lutea Lour.): isolation and properties of a potent stimulant. Science 154:1189-1190. https://doi.org/10.1126/science.154.3753. 1189

Cordeau S, Triolet M, Wayman S et al (2016) Bioherbicides: dead in the water? A review of the existing products for integrated weed management. Crop Prot 87:44-49. https://doi.org/10.1016/j.cropro. 2016.04.016

Crawford S, Shinohara N, Sieberer T et al (2010) Strigolactones enhance competition between shoot branches by dampening auxin transport. Development 137:2905-2913. https://doi.org/10.1242/dev.051987

Dadon T, Nun NB, Mayer AM (2004) A factor from Azospirillum brasilense inhibits germination and radicle growth of Orobanche aegyptiaca. Israel J Plant Sci 52:83-86. https://doi.org/10.1560/ Q3BA-8BJW-W7GH-XHPX

Das TK, Ghosh S, Gupta K et al (2020) The weed Orobanche: species distribution, diversity, biology and management. J Res Weed Sci 3: 162-180. https://doi.org/10.26655/JRWEEDSCI.2020.2.4

Delavault P (2015) Knowing the parasite: biology and genetics of Orobanche. Helia 38:15-29. https://doi.org/10.1515/helia-20140030

Dhanapal GN, Struik PC, Udayakumar M, Timmermans PCJM (1996) Management of broomrape (Orobanche spp.) - a review. J Agron Crop Sci 176:335-359. https://doi.org/10.1111/j.1439-037X.1996. tb00479.x

Dong SQ, Ma YQ, Wu H et al (2012) Stimulatory effects of wheat (Triticum aestivum L.) on seed germination of Orobanche minor Sm. Allelopath J 30:247-258

Dor E, Hershenhorn J (2009) Evaluation of the pathogenicity of microorganisms isolated from Egyptian broomrape (Orobanche aegyptiaca) in Israel. Weed Biol Manag 9:200-208. https://doi. org/10.1111/j.1445-6664.2009.00340.x 
Dor E, Evidente A, Amalfitano C et al (2007) The influence of growth conditions on biomass, toxins and pathogenicity of Fusarium oxysporum f. sp. orthoceras, a potential agent for broomrape biocontrol. Weed Res 47:345-352. https://doi.org/10.1111/j.13653180.2007.00567.x

Dor E, Plakhine D, Joel DM et al (2020) A new race of sunflower broomrape (Orobanche cumana) with a wider host range due to changes in seed response to strigolactones. Weed Sci 68:134-142. https://doi. org/10.1017/wsc.2019.73

Echevarria-Zomeno S, Pérez-de-Luque A, Jorrin J, Maldonado AM (2006) Pre-haustorial resistance to broomrape (Orobanche cumana) in sunflower (Helianthus annuus): cytochemical studies. J Exp Bot 57:4189-4200. https://doi.org/10.1093/jxb/erl195

Egan SP, Zhang L, Comerford M, Hood GR (2018) Botanical parasitism of an insect by a parasitic plant. Curr Biol 28:R863-R864. https:// doi.org/10.1016/j.cub.2018.06.024

Eizenberg H, Aly R, Cohen Y (2012) Technologies for smart chemical control of broomrape (Orobanche spp. and Phelipanche spp.). Weed Sci 60:316-323. https://doi.org/10.1614/WS-D-11-00120.1

Elzein A, Kroschel J, Cadisch G (2008) Efficacy of Pesta granular formulation of Striga-mycoherbicide Fusarium oxysporum f. sp. strigae Foxy 2 after 5-year of storage. J Plant Dis Prot 115:259262. https://doi.org/10.1007/BF03356274

Evidente A, Fernández-Aparicio M, Andolfi A et al (2007) Trigoxazonane, a monosubstituted trioxazonane from Trigonella foenum-graecum root exudate, inhibits Orobanche crenata seed germination. Phytochemistry 68:2487-2492. https://doi.org/10. 1016/j.phytochem.2007.05.016

Fernández-Aparicio M, Emeran AA, Rubiales D (2008) Control of Orobanche crenata in legumes intercropped with fenugreek (Trigonella foenum-graecum). Crop Prot 27:653-659. https://doi. org/10.1016/j.cropro.2007.09.009

Fernández-Aparicio M, Emeran AA, Rubiales D (2010) Inter-cropping with berseem clover (Trifolium alexandrinum) reduces infection by Orobanche crenata in legumes. Crop Prot 29:867-871. https://doi. org/10.1016/j.cropro.2010.03.004

Fernández-Aparicio M, Yoneyama K, Rubiales D (2011) The role of strigolactones in host specificity of Orobanche and Phelipanche seed germination. Seed Sci Res 21:55-61. https://doi.org/10.1017/ S0960258510000371

Fernández-Aparicio M, Reboud X, Gibot-Leclerc S (2016) Broomrape weeds underground mechanisms of \#. Front Plant Sci:7. https://doi. org/10.3389/fpls.2016.00135

Fernández-Aparicio M, Bernard A, Falchetto L et al (2017) Investigation of amino acids as herbicides for control of Orobanche minor parasitism in red clover. Front Plant Sci 8(842). https://doi.org/10.3389/ fpls.2017.00842

Flematti GR, Scaffidi A, Waters MT, Smith SM (2016) Stereospecificity in strigolactone biosynthesis and perception. Planta 243:1361-1373. https://doi.org/10.1007/s00425-016-2523-5

Foo E, Davies NW (2011) Strigolactones promote nodulation in pea. Planta 234:1073-1081. https://doi.org/10.1007/s00425-011-1516-7

Frei B, Guenay Y, Bohan DA et al (2019) Molecular analysis indicates high levels of carabid weed seed consumption in cereal fields across Central Europe. J Pest Sci 92:935-942. https://doi.org/10.1007/ s10340-019-01109-5

Fuerst EP, Okubara PA, Anderson JV, Morris CF (2014) Polyphenol oxidase as a biochemical seed defense mechanism. Front Plant Sci:5. https://doi.org/10.3389/fpls.2014.00689

Gaba S, Perronne R, Fried G et al (2017) Response and effect traits of arable weeds in agro-ecosystems: a review of current knowledge. Weed Res 57:123-147. https://doi.org/10.1111/wre.12245

Gacheru E, Rao MR (2005) The potential of planted shrub fallows to combat Striga infestation on maize. Int J Pest Manag 51:91-100. https://doi.org/10.1080/09670870400028292
Gallardo-López F, Hernández-Chontal M, Cisneros-Saguilán P, LinaresGabriel A (2018) Development of the concept of agroecology in Europe: a review. Sustainability 10:1210. https://doi.org/10.3390/ su10041210

Gbèhounou G, Adango E (2003) Trap crops of Striga hermonthica: in vitro identification and effectiveness in situ. Crop Prot 22:395404. https://doi.org/10.1016/S0261-2194(02)00196-5

Gebretsadik R, Shimelis H, Laing MD et al (2013) Evaluation of Sorghum genotypes compatibility with Fusarium oxysporum under Striga infestation. Crop Sci 53:385-393. https://doi.org/10.2135/ cropsci2012.02.0101

Gibot-Leclerc S, Brault M, Pinochet X, Sallé G (2003) Potential role of winter rape weeds in the extension of broomrape in PoitouCharentes. C R Biol 326:645-658. https://doi.org/10.1016/S16310691(03)00169-0

Gibot-Leclerc S, Sallé G, Reboud X, Moreau D (2012) What are the traits of Phelipanche ramosa (L.) Pomel that contribute to the success of its biological cycle on its host Brassica napus L.? Flora - Morphol Distrib Funct Ecol Plants 207:512-521. https://doi.org/10.1016/j. flora.2012.06.011

Gibot-Leclerc S, Dessaint F, Reibel C, Le Corre V (2013) Phelipanche ramosa (L.) Pomel populations differ in life-history and infection response to hosts. Flora - Morphol Distrib Funct Ecol Plants 208: 247-252. https://doi.org/10.1016/j.flora.2013.03.007

Gibot-Leclerc S, Reibel C, Le Corre V, Dessaint F (2015) Unexpected fast development of branched broomrape on slow-growing Brassicaceae. Agron Sustain Dev 35:151-156. https://doi.org/10. 1007/s13593-014-0217-6

Gibot-Leclerc S, Perronne R, Dessaint F et al (2016) Assessment of phylogenetic signal in the germination ability of Phelipanche ramosa on Brassicaceae hosts. Weed Res 56:452-461. https://doi. org/10.1111/wre. 12222

Gilbert GS, Magarey R, Suiter K, Webb CO (2012) Evolutionary tools for phytosanitary risk analysis: phylogenetic signal as a predictor of host range of plant pests and pathogens. Evol Appl 5:869-878. https://doi.org/10.1111/j.1752-4571.2012.00265.x

Gobena D, Shimels M, Rich PJ et al (2017) Mutation in sorghum LOW GERMINATION STIMULANT 1 alters strigolactones and causes Striga resistance. Proc Natl Acad Sci U S A 114:4471-4476. https://doi.org/10.1073/pnas.1618965114

Gomez-Roldan V, Fermas S, Brewer PB et al (2008) Strigolactone inhibition of shoot branching. Nature 455:189-194. https://doi.org/10. 1038/nature07271

Goto R, Yamakoshi G, Matsuzawa T (2012) A novel brood-site pollination mutualism?: the root holoparasite Thonningia sanguinea (Balanophoraceae) and an inflorescence-feeding fly in the tropical rainforests of West Africa. Plant Species Biol 27:164-169. https:// doi.org/10.1111/j.1442-1984.2011.00338.x

Goyet V, Billard E, Pouvreau J-B et al (2017) Haustorium initiation in the obligate parasitic plant Phelipanche ramosa involves a hostexudated cytokinin signal. J Exp Bot 68:5539-5552. https://doi. org/10.1093/jxb/erx359

Gurney AL, Slate J, Press MC, Scholes JD (2006) A novel form of resistance in rice to the angiosperm parasite Striga hermonthica. New Phytol 169:199-208. https://doi.org/10.1111/j.1469-8137. 2005.01560.x

van Halder I, Castagneyrol B, Ordóñez C et al (2019) Tree diversity reduces pine infestation by mistletoe. For Ecol Manag 449: 117470. https://doi.org/10.1016/j.foreco.2019.117470

Haran J (2018) A review of the genus Smicronyx Schoenherr (Coleoptera, Curculionidae, Curculioninae) in tropical Africa. Zootaxa 4508:267. https://doi.org/10.11646/zootaxa.4508.2.9

Haring SC, Flessner ML (2018) Improving soil seed bank management: improving soil seed bank management. Pest Manag Sci 74:24122418. https://doi.org/10.1002/ps.5068 
Hatcher PE, Froud-Williams RJ (eds.) (2017) Weed Research: Expanding Horizons. John Wiley \& Sons, Ltd, Hoboken, p 432. https://doi.org/10.1002/9781119380702

Hegenauer V, Körner M, Albert M (2017) Plants under stress by parasitic plants. Curr Opin Plant Biol 38:34-41. https://doi.org/10.1016/j.pbi. 2017.04.006

Heide-Jørgensen H (2008) Parasitic flowering plants. 438p. Leiden ; Boston : Brill. https://brill.com/view/title/15231. Accessed Feb 2021

Hemissi I, Mabrouk Y, Abdi N et al (2013) Growth promotion and protection against Orobanche foetida of chickpea (Cicer aerietinum) by two Rhizobium strains under greenhouse conditions. Afr J Biotechnol 12:1371-1377. https://doi.org/10.5897/AJB12.2161

Hemmati R, Gholizadeh R (2019) Talaromyces trachyspermus a potential biocontrol agent for branched broomrape (Orobanche ramosa). Australas Plant Pathol 48:217-219. https://doi.org/10.1007/s13313019-0620-1

Hershenhorn J, Goldwasser Y, Plakhine D et al (1996) Role of pepper (Capsicum annuum) as a trap and catch crop for control of Orobanche aegyptiaca and O. cernua. Weed Sci 44:948-951

Hershenhorn J, Eizenberg H, Dor E et al (2009) Phelipanche aegyptiaca management in tomato. Weed Res 49:34-47. https://doi.org/10. 1111/j.1365-3180.2009.00739.x

Holst N, Rasmussen IA, Bastiaans L (2007) Field weed population dynamics: a review of model approaches and applications. Weed Res 47:1-14. https://doi.org/10.1111/j.1365-3180.2007.00534.x

Houngbédji T, Dessaint F, Nicolardot B et al (2016) Weed communities of rain-fed lowland rice vary with infestation by Rhamphicarpa fistulosa. Acta Oecol 77:85-90. https://doi.org/10.1016/j.actao. 2016.09.004

Houngbédji T, Dessaint F, Nicolardot B et al (2020) Abundance of Rhamphicarpa fistulosa in rainfed lowland rice fields in the Savannah region of Togo: moderate influence of physico-chemical characteristics of soils. Weed Res 00:1-7. https://doi.org/10.1111/ wre. 12446

Huet S, Pouvreau J-B, Delage E et al (2020) Populations of the parasitic plant Phelipanche ramosa influence their seed microbiota. Front Plant Sci:11. https://doi.org/10.3389/fpls.2020.01075

Jaiswal SK, Shivaji SS, Singh A (2018) Weed management through insects. In: Recent trends in integrated Pest and disease management. Weser Books, Zittau Germeny, pp 166-173

Jamil M, Rodenburg J, Charnikhova T, Bouwmeester HJ (2011) Preattachment Striga hermonthica resistance of new rice for Africa (NERICA) cultivars based on low strigolactone production. New Phytol 192:964-975. https://doi.org/10.1111/j.1469-8137.2011. 03850.x

Jebri M, Ben Khalifa M, Fakhfakh H et al (2018) Genetic diversity and race composition of sunflower broomrape populations from Tunisia. Phytopathol Mediterr 56. https://doi.org/10.14601/Phytopathol Mediterr-20839

Jensen PK (2018) Use of integrated weed management tools in crop rotations with grass seed production. Soil \& Plant Sci 69:209-218. https://doi.org/10.1080/09064710.2018.1530295

Joel DM (2009) The new nomenclature of Orobanche and Phelipanche. Weed Res 49:6-7. https://doi.org/10.1111/j.1365-3180.2009.00748. $\mathrm{x}$

Joel DM (2013) The haustorium and the life cycles of parasitic Orobanchaceae. In: Joel DM, Gressel J, Musselman LJ (eds) Parasitic Orobanchaceae: parasitic mechanisms and control strategies. Springer, Berlin, Heidelberg, pp 21-23

Kaiser B, Vogg G, Fürst UB, Albert M (2015) Parasitic plants of the genus Cuscuta and their interaction with susceptible and resistant host plants. Front Plant Sci 6:1-5. https://doi.org/10.3389/fpls.2015. 00045

Kakhaki SHN, Montazeri M, Naseri B (2017) Biocontrol of broomrape using Fusarium oxysporum f. sp orthoceras in tomato crops under field conditions. Biocontrol Sci Tech 27:1435-1444. https://doi.org/ 10.1080/09583157.2017.1409338

Khan ZR, Hassanali A, Overholt W et al (2002) Control of witchweed Striga hermonthica by intercropping with Desmodium spp., and the mechanisms defined as allelopathic. J Chem Ecol 28:15

Khan ZR, Pickett JA, Wadhams LJ et al (2006) Combined control of Striga hermonthica and stemborers by maize-Desmodium spp. intercrops. Crop Prot 25:989-995. https://doi.org/10.1016/j.cropro. 2006.01.008

Khosla A, Nelson DC (2016) Strigolactones, super hormones in the fight against Striga. Curr Opin Plant Biol 33:57-63. https://doi.org/10. 1016/j.pbi.2016.06.001

Klein O, Kroschel J (2002) Biological control of Orobanche spp. with Phytomyza orobanchia, a review. Biol Control 47:245-277

Kokla A, Melnyk CW (2018) Developing a thief: Haustoria formation in parasitic plants. Dev Biol 442:53-59. https://doi.org/10.1016/j. ydbio.2018.06.013

Kruh LI, Lahav T, Abu-Nassar J et al (2017) Host-parasite-bacteria triangle: the microbiome of the parasitic weed Phelipanche aegyptiaca and tomato-Solanum lycopersicum (Mill.) as a host. Front Plant Sci 8. https://doi.org/10.3389/fpls.2017.00269

Krupp A, Rücker E, Heller A, Spring O (2015) Seed structure characteristics of Orobanche cumana populations. Helia 38:1-14. https://doi. org/10.1515/helia-2014-0034

Krupp A, Heller A, Spring O (2019) Development of phloem connection between the parasitic plant Orobanche cumana and its host sunflower. Protoplasma 256:1385-1397. https://doi.org/10.1007/s00709$019-01393-z$

Kuijt J (1969) The biology of parasitic flowering plants. University of California Press, Berkeley

Le Corre V, Reibel C, Gibot-Leclerc S (2014) Development of microsatellite markers in the branched broomrape Phelipanche ramosa $\mathrm{L}$. (Pomel) and evidence for host-associated genetic divergence. IJMS 15:994-1002. https://doi.org/10.3390/ijms15010994

LeBlanc M, Kim G, Westwood JH (2012) RNA trafficking in parasitic plant systems. Front Plant Sci 3. https://doi.org/10.3389/fpls.2012. 00203

Lee KB, Jernstedt JA (2013) Defense response of resistant host Impatiens balsamina to the parasitic angiosperm Cuscuta japonica. J Plant Biol 56:138-144. https://doi.org/10.1007/s12374-013-0011-z

Lewis KC, Alers-García J, Wright LJ (2010) Green tea catechins applied to susceptible hosts inhibit parasitic plant attachment success. Crop Sci 50:253-264. https://doi.org/10.2135/cropsci2008.12.0720

Li J, Timko MP (2009) Gene-for-gene resistance in Striga-cowpea associations. Science 325:1094-1094. https://doi.org/10.1126/science. 1174754

Li J, Oduor AMO, Yu F, Dong M (2019) A native parasitic plant and soil microorganisms facilitate a native plant co-occurrence with an invasive plant. Ecol Evol 9:8652-8663. https://doi.org/10.1002/ece3. 5407

Lins RD, Colquhoun JB, Mallory-Smith CA (2006) Investigation of wheat as a trap crop for control of Orobanche minor. Weed Res 46:313-318. https://doi.org/10.1111/j.1365-3180.2006.00515.x

Liu H, Brettell LE (2019) Plant defense by VOC-induced microbial priming. Trends Plant Sci 24:187-189. https://doi.org/10.1016/j.tplants. 2019.01 .008

Lombard V, Golaconda Ramulu H, Drula E et al (2014) The carbohydrate-active enzymes database (CAZy) in 2013. Nucleic Acids Res 42:D490-D495. https://doi.org/10.1093/nar/gkt1178

Louarn J, Boniface M-C, Pouilly N et al (2016) Sunflower resistance to broomrape (Orobanche cumana) is controlled by specific QTLs for different parasitism stages. Front Plant Sci 7:1-14. https://doi.org/ $10.3389 /$ fpls.2016.00590

Lushchak VI, Matviishyn TM, Husak VV et al (2018) Pesticide toxicity: a mechanistic approach. EXCLI J 17:1101-1136. https://doi.org/10. 17179/EXCLI2018-1710 
Malek J, del Moral L, Fernandez-Escobar J et al (2017) Racial characterization and genetic diversity of sunflower broomrape populations from Northern Spain. Phytopathol Mediterr 56:70-76. https://doi. org/10.14601/Phytopathol_Mediterr-19163

Mangnus EM, Dommerholt FJ, De Jong RLP, Zwanenburg B (1992) Improved synthesis of strigol analog GR24 and evaluation of the biological activity of its diastereomers. J Agric Food Chem 40: 1230-1235. https://doi.org/10.1021/jf00019a031

Manschadi AM, Wang E, Robertson MJ et al (2003) Development of a parasite module in APSIM - case study: the parasitic weed Orobanche crenata infesting faba bean. Australian Society of Agronomy, Geelong, Victoria

Mauro RP, Lo Monaco A, Lombardo S et al (2015) Eradication of Orobanche/Phelipanche spp. seedbank by soil solarization and organic supplementation. Sci Hortic 193:62-68. https://doi.org/10. 1016/j.scienta.2015.06.038

Mauromicale G, Monaco AL, Longo AMG, Restuccia A (2005) Soil solarization, a nonchemical method to control branched broomrape (Orobanche ramosa) and improve the yield of greenhouse tomato. Wees 53:877-883. https://doi.org/10.1614/WS-05-023R1.1

Mazzola M (2002) Mechanisms of natural soil suppressiveness to soilborne diseases. Antonie Van Leeuwenhoek 81:557-564 200135319-09922

McAdam EL, Hugill C, Fort S et al (2017) Determining the site of action of strigolactones during nodulation. Plant Physiol 175:529-542. https://doi.org/10.1104/pp.17.00741

McNeal JR, Bennett JR, Wolfe AD, Mathews S (2013) Phylogeny and origins of holoparasitism in Orobanchaceae. Am J Bot 100:971983. https://doi.org/10.3732/ajb.1200448

Mellado A, Zamora R (2016) Spatial heterogeneity of a parasitic plant drives the seed-dispersal pattern of a zoochorous plant community in a generalist dispersal system. Funct Ecol 30:459-467. https://doi. org/10.1111/1365-2435.12524

Melnyk CW, Meyerowitz EM (2015) Plant grafting. Curr Biol 25:R183R188. https://doi.org/10.1016/j.cub.2015.01.029

Mendes R, Kruijt M, de Bruijn I et al (2011) Deciphering the rhizosphere microbiome for disease-suppressive bacteria. Science 332:10971100. https://doi.org/10.1126/science.1203980

Miché L, Bouillant M-L, Rohr R et al (2000) Physiological and cytological studies on the inhibition of Striga seed germination by the plant growth-promoting bacterium Azospirillum brasilense. Eur J Plant Pathol 106:347-351

Midega CAO, Wasonga CJ, Hooper AM et al (2017) Drought-tolerant Desmodium species effectively suppress parasitic striga weed and improve cereal grain yields in western Kenya. Crop Prot 98:94-101. https://doi.org/10.1016/j.cropro.2017.03.018

Mitschunas N, Filser J, Wagner M (2009) On the use of fungicides in ecological seed burial studies. Seed Sci Res 19:51-60. https://doi. org/10.1017/S096025850818727X

Moënne-Loccoz Y, Mavingui P, Combes C et al (2015) Microorganisms and biotic interactions. In: Bertrand J-C, Caumette P, Lebaron P et al (eds) Environmental microbiology: fundamentals and applications. Springer Netherlands, Dordrecht, pp 395-444

Mrema E, Shimelis H, Laing M, Bucheyeki T (2017) Screening of sorghum genotypes for resistance to Striga hermonthica and S. asiatica and compatibility with Fusarium oxysporum f.sp. strigae. Acta Agric Scand Sect B Soil Plant Sci 67:395-404. https://doi.org/10. 1080/09064710.2017.1284892

Müller-Stöver D, Kohlschmid E, Sauerborn J (2008) A novel strain of Fusarium oxysporum from Germany and its potential for biocontrol of Orobanche ramosa: biocontrol of Orobanche ramosa. Weed Res 49:175-182. https://doi.org/10.1111/j.1365-3180.2008.00686.x

Ndambi B, Cadisch G, Elzein A, Heller A (2011) Colonization and control of Striga hermonthica by Fusarium oxysporum f. sp. strigae, a mycoherbicide component: an anatomical study. Biol Control 58: 149-159. https://doi.org/10.1016/j.biocontrol.2011.04.015
Neve P, Barney JN, Buckley Y et al (2018) Reviewing research priorities in weed ecology, evolution and management: a horizon scan. Weed Res 58:250-258. https://doi.org/10.1111/wre.12304

Nzioki HS, Oyosi F, Morris CE et al (2016) Striga biocontrol on a toothpick: a readily deployable and inexpensive method for smallholder farmers. Front Plant Sci 7. https://doi.org/10.3389/fpls.2016.01121

Oerke E-C (2006) Crop losses to pests. J Agric Sci 144:31-43. https://doi. org $/ 10.1017 / \mathrm{S} 0021859605005708$

Oswald A, Ransom JK, Kroschel J, Sauerborn J (2002) Intercropping controls Striga in maize based farming systems. Crop Prot 21: 367-374. https://doi.org/10.1016/S0261-2194(01)00104-1

Othira JO, Deng AL, Onek LA et al (2008) Potential application of Hyptis spicigera for biological control of Striga hermonthica infestation. Afr J Agric Res 3:747-752

Palomo-Campesino S, González J, García-Llorente M (2018) Exploring the connections between agroecological practices and ecosystem services: a systematic literature review. Sustainability 10:4339. https://doi.org/10.3390/su10124339

Pardo G, Riravololona M, Munier-Jolain NM (2010) Using a farming system model to evaluate cropping system prototypes: are labour constraints and economic performances hampering the adoption of integrated weed management? Eur J Agron 33:24-32. https://doi. org/10.1016/j.eja.2010.02.003

Parker C (2009) Observations on the current status of Orobanche and Striga problems worldwide. Pest Manag Sci 65:453-459. https:// doi.org/10.1002/ps.1713

Parker C (2013) The parasitic weeds of the Orobanchaceae. In: Joel DM, Gressel J, Musselman LJ (eds) Parasitic Orobanchaceae: parasitic mechanisms and control strategies. Springer, Berlin, Heidelberg, pp 313-344

Parker C, Riches CR (1993) Parasitic weeds of the world: biology and control. Parasitic weeds of the world: biology and control. 332p. CAB International, University of Arizona Press, Tucson

Penuelas J, Llusia J (2004) Plant VOC emissions: making use of the unavoidable. Trends Ecol Evol 19:402-404. https://doi.org/10. 1016/j.tree.2004.06.002

Pérez-De-Luque A, Fondevilla S, Pérez-Vich B et al (2009) Understanding Orobanche and Phelipanche -host plant interactions and developing resistance. Weed Res 49:8-22. https://doi.org/10. 1111/j.1365-3180.2009.00738.x

Perronne R, Gibot-Leclerc S, Dessaint F et al (2017) Is induction ability of seed germination of Phelipanche ramosa phylogenetically structured among hosts? A case study on Fabaceae species. Genetica 145: 481-489. https://doi.org/10.1007/s10709-017-9990-х

Pickett JA, Hamilton ML, Hooper AM et al (2010) Companion cropping to manage parasitic plants. Annu Rev Phytopathol 48:161-177. https://doi.org/10.1146/annurev-phyto-073009-114433

Pointurier O, Gibot-Leclerc S, Le Corre V et al (2019) Intraspecific seasonal variation of dormancy and mortality of Phelipanche ramosa seeds. Weed Res 50:407-418. https://doi.org/10.1111/wre.12378

Pollard AT (2018) Seeds vs fungi: an enzymatic battle in the soil seedbank. Seed Sci Res 28:197-214. https://doi.org/10.1017/ S0960258518000181

Poulin R (2014) Parasite biodiversity revisited: frontiers and constraints. Int J Parasitol 44:581-589. https://doi.org/10.1016/j.ijpara.2014.02. 003

Press MC, Phoenix GK (2005) Impacts of parasitic plants on natural communities: Tansley review. New Phytol 166:737-751. https:// doi.org/10.1111/j.1469-8137.2005.01358.x

Qasem JR (2019) Branched broomrape (Orobanche ramosa L.) control in tomato (Lycopersicon esculentum Mill.) by trap crops and other plant species in rotation. Crop Prot 120:75-83. https://doi.org/10. 1016/j.cropro.2019.02.021

Qasem JR, Issa NN (2018) Germination and growth management of some common annual weeds by phytotoxicity of selected vegetable 
crops. Sci Hortic 233:431-445. https://doi.org/10.1016/j.scienta. 2017.12.023

Raaijmakers JM, Mazzola M (2016) Soil immune responses. Science 352:1392-1393. https://doi.org/10.1126/science.aaf3252

Raaijmakers JM, Paulitz TC, Alabouvette C et al (2009) The rhizosphere: a playground and battlefield for soilborne pathogens and beneficial microorganisms. Plant Soil 321:341-361. https://doi.org/10.1007/ s11104-11008-19568-11106

Rial C, Tomé S, Varela RM et al (2020) Phytochemical study of safflower roots (Carthamus tinctorius) on the induction of parasitic plant germination and weed control. J Chem Ecol 46:871-880. https://doi. org/10.1007/s10886-020-01200-7

Rodenburg J, Morawetz JJ, Bastiaans L (2015) Rhamphicarpa fistulosa, a widespread facultative hemi-parasitic weed, threatening rice production in Africa. Weed Res 55:118-131. https://doi.org/10.1111/wre. 12129

Rodenburg J, Demont M, Zwart SJ, Bastiaans L (2016) Parasitic weed incidence and related economic losses in rice in Africa. Agric Ecosyst Environ 235:306-317. https://doi.org/10.1016/j.agee.2016. 10.020

Rodriguez CE, Mitter B, Barret M et al (2018) Commentary: seed bacterial inhabitants and their routes of colonization. Plant Soil 422:129 134. https://doi.org/10.1007/s11104-017-3368-9

Ross KC, Colquhoun JB, Mallory-Smith CA (2004) Small broomrape (Orobanche minor) germination and early development in response to plant species. Weed Sci 52(2):260-266. https://doi.org/10.1614/ ws-03-088r1

Rubiales D (2018) Can we breed for durable resistance to broomrapes? Phytopathol Mediterr 57:170-185. https://doi.org/10.14601/ Phytopathol_Mediterr-22543

Runyon JB, Tooker JF, Mescher MC, De Moraes CM (2009) Parasitic plants in agriculture: chemical ecology of germination and hostplant location as targets for sustainable control: a review. In: Lichtfouse E (ed) Organic farming, Pest Control and Remediation of Soil Pollutants. Springer Netherlands, Dordrecht, pp 123-136

Salliou N, Barnaud C (2017) Landscape and biodiversity as new resources for agro-ecology? Insights from farmers' perspectives. E\&S 22(2):16. https://doi.org/10.5751/ES-09249-220216

Sanchez Pedraja O, Moreno Moral G, Carlon L, Piwowarczyk R, Lainz M, Schneeweiss GM (2005) Index of Orobanchaceae. http://www. farmalierganes.com/Otrospdf/publica/Orobanchaceae\%20Index. htm. Accessed Feb 2021

Satovic Z, Joel DM, Rubiales D et al (2009) Population genetics in weedy species of Orobanche. Australas Plant Pathol 38:228. https://doi. org/10.1071/AP08100

Sauerborn J, Müller-Stöver D, Hershenhorn J (2007) The role of biological control in managing parasitic weeds. Crop Prot 26:246-254. https://doi.org/10.1016/j.cropro.2005.12.012

Scavo A, Mauromicale G (2020) Integrated weed management in herbaceous field crops. Agronomy 10:466. https://doi.org/10.3390/ agronomy 10040466

Scavo A, Restuccia A, Mauromicale G (2018) Allelopathy: principles and basic aspects for agroecosystem control. In: Gaba S, Smith B, Lichtfouse E (eds) Sustainable agriculture reviews 28: ecology for agriculture. Springer International Publishing, Cham, pp 47-101

Scavo A, Abbate C, Mauromicale G (2019) Plant allelochemicals: agronomic, nutritional and ecological relevance in the soil system. Plant Soil 442:23-48. https://doi.org/10.1007/s11104-019-04190-y

Schädler M, Roeder M, Brandl R, Matthies D (2005) Is palatability of a root-hemiparasitic plant influenced by its host species? Oecologia 146:227-233. https://doi.org/10.1007/s00442-005-0192-3

Scherner A, Melander B, Kudsk P (2016) Vertical distribution and composition of weed seeds within the plough layer after eleven years of contrasting crop rotation and tillage schemes. Soil Tillage Res 161: 135-142. https://doi.org/10.1016/j.still.2016.04.005
Schiltz S, Gaillard I, Pawlicki-Jullian N et al (2015) A review: what is the spermosphere and how can it be studied? J Appl Microbiol 119: 1467-1481. https://doi.org/10.1111/jam.12946

Schneider AC, Colwell AEL, Schneeweiss GM, Baldwin BG (2016) Cryptic host-specific diversity among western hemisphere broomrapes (Orobanche s.l. , Orobanchaceae). Ann Bot 118:1101-1111. https://doi.org/10.1093/aob/mcw158

Shabana YM, Müller-Stöver D, Sauerborn J (2003) Granular Pesta formulation of Fusarium oxysporum f. sp. orthoceras for biological control of sunflower broomrape: efficacy and shelf-life. Biol Control 26:189-201. https://doi.org/10.1016/S1049-9644(02) 00130-5

Shahid S, Kim G, Johnson NR et al (2018) MicroRNAs from the parasitic plant Cuscuta campestris target host messenger RNAs. Nature 553: 82-85. https://doi.org/10.1038/nature25027

Siegel-Hertz K, Edel-Hermann V, Chapelle E et al (2018) Comparative microbiome analysis of a Fusarium wilt suppressive soil and a Fusarium wilt conducive soil from the Châteaurenard region. Front Microbiol 9:568. https://doi.org/10.3389/fmicb.2018.00568

Soto MJ, Fernández-Aparicio M, Castellanos-Morales V et al (2010) First indications for the involvement of strigolactones on nodule formation in alfalfa (Medicago sativa). Soil Biol Biochem 42:383-385. https://doi.org/10.1016/j.soilbio.2009.11.007

Spallek T, Mutuku M, Shirasu K (2013) The genus Striga : a witch profile: profile of Striga, the witchweed. Mol Plant Pathol 14:861869. https://doi.org/10.1111/mpp.12058

Srivastava US, Jaiswal AK (1990) Insect growth regulatory activity in the parasitic plant Cuscuta reflexa Roxb. (Convolvulaceae). Natl Acad Sci Lett -India 13:137-140

Steinberg C, Edel-Hermann V, Alabouvette C, Lemanceau P (2019) Soil suppressiveness to plant diseases. In: Van Elsas JD, Trevors JT, Rosaldo AS, Nannipieri P, (eds) Modern Soil Microbiology- Third Edition. CRC Press (Taylor \& Francis Group), pp 345-361

Stewart GR, Press MC (1990) The physiology and biochemistry of parasitic angiosperms. Annu Rev Plant Physiol Plant Mol Biol 41:1271512. https://doi.org/10.1146/annurev.pp.41.060190.001015

Stojanova B, Delourme R, Duffé P et al (2019) Genetic differentiation and host preference reveal non-exclusive host races in the generalist parasitic weed Phelipanche ramosa. Weed Res 59:107-118. https:// doi.org/10.1111/wre.12353

Swarbrick PJ, Huang K, Liu G et al (2008) Global patterns of gene expression in rice cultivars undergoing a susceptible or resistant interaction with the parasitic plant Striga hermonthica. New Phytol 179:515-529. https://doi.org/10.1111/j.1469-8137.2008. 02484.x

Takahashi I, Asami T (2018) Target-based selectivity of strigolactone agonists and antagonists in plants and their potential use in agriculture. J Exp Bot 69:2241-2254. https://doi.org/10.1093/jxb/ery126

Teka HB (2014) Advance research on Striga control: a review. African J Plant Sci 8:492-506

Těšitel J (2016) Functional biology of parasitic plants: a review. Plecevo 149:5-20. https://doi.org/10.5091/plecevo.2016.1097

Thiele H-U (1977) Carabid beetles in their environments. Springer, Berlin, Heidelberg

Thomas H, Heller A, Sauerborn J, Muller-Stover D (1999) Fusarium oxysporum f. sp. orthoceras, a potential mycoherbicide, parasitizes seeds of Orobanche cumana (sunflower broomrape): a cytological study. Ann Bot 83:453-458. https://doi.org/10.1006/anbo.1998. 0847

Tóth P, Undas AK, Verstappen F, Bouwmeester H (2016) Floral volatiles in parasitic plants of the Orobanchaceae. Ecological and taxonomic implications. Front Plant Sci 7:1-15. https://doi.org/10.3389/fpls. 2016.00312

Trezzi MM, Vidal RA, Balbinot Junior AA et al (2016) Allelopathy: driving mechanisms governing its activity in agriculture. J Plant Interact 11:53-60. https://doi.org/10.1080/17429145.2016.1159342 
Tsuchiya Y (2018) Small molecule toolbox for strigolactone biology. Plant Cell Physiol 59:1511-1519. https://doi.org/10.1093/pcp/ pcy119

Twyford AD (2018) Parasitic plants. Curr Biol 28:R857-R859. https:// doi.org/10.1016/j.cub.2018.06.030

Ullrich SD, Buyer JS, Cavigelli MA et al (2011) Weed seed persistence and microbial abundance in long-term organic and conventional cropping systems. Weed Sci 59:202-209. https://oi.org/10.1614/ WS-D-10-00142.1

Van Bruggen AHC, He MM, Shin K et al (2018) Environmental and health effects of the herbicide glyphosate. Sci Total Environ 616 617:255-268. https://doi.org/10.1016/j.scitotenv.2017.10.309

Vila-Aiub (2019) Fitness of herbicide-resistant weeds: current knowledge and implications for management. Plants 8:469. https://doi.org/10. 3390/plants 8110469

Vincent D, Rafiqi M, Job D (2020) The multiple facets of plant-fungal interactions revealed through plant and fungal secretomics. Front Plant Sci 10:1626. https://doi.org/10.3389/fpls.2019.01626

Vurro M, Boari A, Pilgeram AL, Sands DC (2006) Exogenous amino acids inhibit seed germination and tubercle formation by Orobanche ramosa (broomrape): potential application for management of parasitic weeds. Biol Control 36:258-265. https://doi.org/10.1016/j. biocontrol.2005.09.017

Vurro M, Prandi C, Baroccio F (2016) Strigolactones: how far is their commercial use for agricultural purposes?: Strigolactones in agriculture. Pest Manag Sci 72:2026-2034. https://doi.org/10.1002/ps. 4254

Wang Y, Bouwmeester HJ (2018) Structural diversity in the strigolactones. J Exp Bot 69:2219-2230. https://doi.org/10.1093/ jxb/ery091

Westphal A, Becker JO (2001) Soil suppressiveness to Heterodera schachtii under different cropping sequences. Nematology 3:551558. https://doi.org/10.1163/156854101753389167

Westwood JH (2013) The physiology of the established parasite-host association. In: Joel DM, Gressel J, Musselman LJ (eds) Parasitic Orobanchaceae: parasitic mechanisms and control strategies. Springer, Berlin, Heidelberg, pp 87-114

Westwood JH, Yoder JI, Timko MP, dePamphilis CW (2010) The evolution of parasitism in plants. Trends Plant Sci 15:227-235. https:// doi.org/10.1016/j.tplants.2010.01.004

Wezel A, Bellon S, Doré T et al (2009) Agroecology as a science, a movement and a practice. A review. Agron Sustain Dev 29:503515. https://doi.org/10.1051/agro/2009004

Xiao Z, Zou T, Lu S, Xu Z (2020) Soil microorganisms interacting with residue-derived allelochemicals effects on seed germination. Saudi J Biol Sci 27:1057-1065. https://doi.org/10.1016/j.sjbs.2020.01.013

Yao R, Li J, Xie D (2018) Recent advances in molecular basis for strigolactone action. Sci China Life Sci 61:277-284. https://doi. org/10.1007/s11427-017-9195-x

Ye X, Jia J, Ma Y et al (2016) Effectiveness of ten commercial maize cultivars in inducing Egyptian broomrape germination. Front Agric Sci Eng 3:137. https://doi.org/10.15302/J-FASE-2016098

Yoder JI, Scholes JD (2010) Host plant resistance to parasitic weeds; recent progress and bottlenecks. Curr Opin Plant Biol 13:478-484. https://doi.org/10.1016/j.pbi.2010.04.011
Yoneyama K, Arakawa R, Ishimoto K et al (2015) Difference in Striga susceptibility is reflected in strigolactone secretion profile, but not in compatibility and host preference in arbuscular mycorrhizal symbiosis in two maize cultivars. New Phytol 206:983-989. https://doi. org/10.1111/nph.13375

Yoshida S, Shirasu K (2009) Multiple layers of incompatibility to the parasitic witchweed, Striga hermonthica. New Phytol 183:180 189. https://doi.org/10.1111/j.1469-8137.2009.02840.x

Yoshida S, Shirasu K (2012) Plants that attack plants: molecular elucidation of plant parasitism. Curr Opin Plant Biol 15:708-713. https:// doi.org/10.1016/j.pbi.2012.07.004

Yoshida S, Cui S, Ichihashi Y, Shirasu K (2016) The haustorium, a specialized invasive organ in parasitic plants. Annu Rev Plant Biol 67:643-667. https://doi.org/10.1146/annurev-arplant-043015111702

de Zélicourt A, Letousey P, Thoiron S et al (2007) Ha-DEF1, a sunflower defensin, induces cell death in Orobanche parasitic plants. Planta 226(3):591-600. https://doi.org/10.1007/s00425-007-0507-1

Zermane N, Souissi T, Kroschel J, Sikora R (2007) Biocontrol of broomrape (Orobanche crenata Forsk. and Orobanche foetida Poir.) by Pseudomonas fluorescens isolate Bf7-9 from the faba bean rhizosphere. Biocontrol Sci Tech 17:483-497. https://doi.org/10.1080/ 09583150701309535

Zhang M, Zeiss MR, Geng S (2015) Agricultural pesticide use and food safety: California's model. J Integr Agric 14:2340-2357. https://doi. org/10.1016/S2095-3119(15)61126-1

Zwanenburg B, Blanco-Ania D (2018) Strigolactones: new plant hormones in the spotlight. J Exp Bot 69:2205-2218. https://doi.org/ $10.1093 /$ jxb/erx487

Zwanenburg B, Pospiśíl T (2013) Structure and activity of strigolactones: new plant hormones with a rich future. Mol Plant 6:38-62. https:// doi.org/10.1093/mp/sss 141

Zwanenburg B, Nayak SK, Charnikhova TV, Bouwmeester HJ (2013) New strigolactone mimics: structure-activity relationship and mode of action as germinating stimulants for parasitic weeds. Bioorg Med Chem Lett 23:5182-5186. https://doi.org/10.1016/j.bmcl.2013.07. 004

Zwanenburg B, Mwakaboko AS, Kannan C (2016) Suicidal germination for parasitic weed control: suicidal germination for parasitic weed control. Pest Manag Sci 72:2016-2025. https://doi.org/10.1002/ps. 4222

This bibliographic review was carried out as part of the Dinia Cartry's $\mathrm{PhD}$ thesis, funded by the Bourgogne Franche Comté Region (909/ UB18228.AGR.CL OROBANCHI-SEED).

Publisher's note Springer Nature remains neutral with regard to jurisdictional claims in published maps and institutional affiliations. 